Cómo citar / How to cite: Benedito Nuez, J., Ferrer Maestro, J.J. y Melchor Monserrat, J.M. 2020. De la Tardoantigüedad al Medievo: un enfoque crítico acerca de los estudios arqueológicos en la ciudad de Saguntum y su territorio en época visigoda. Antigüedad y Cristianismo 37, 5-28. https:/doi.org/10.6018/ayc.458741

\title{
De la TARdoantigüedad al Medievo: un enfoque Crítico ACERCA DE LOS ESTUDIOS ARQUEOLÓGICOS EN LA CIUDAD DE SAGUNTUM Y SU TERRITORIO EN ÉPOCA VISIGODA
}

\section{From late Antiquity to the Middle Ages: a Critical approach to ARCHAEOLOGICAL STUDIES IN THE CITY OF SAGUNTUM AND ITS TERRITORY IN THE VISIGOTHIC PERIOD}

\author{
Josep Benedito Nuez \\ Universitat Jaume I, \\ Castellón de la Plana, España \\ jbenedit@uji.es \\ orcid.org/0000-0002-1095-6079
}

\author{
Juan José Ferrer Maestro \\ Universitat Jaume I, \\ Castellón de la Plana, España \\ jferrer@uji.es \\ orcid.org/0000-0003-3921-6418
}

\author{
José Manuel Melchor Monserrat \\ Museo Arqueológico de Burriana, \\ Burriana, España \\ arqueologo@burriana.es \\ orcid.org/0000-0002-8834-4240
}

Recibido: 25-5-2020

Aceptado: 23-09-2020

\section{RESUMEN}

El hallazgo de restos materiales de época visigoda en torno a Sagunto, no alcanza a entrever cual sería la consideración de este territorio situado a caballo de las actuales provincias de Valencia y Tarragona. Con este trabajo se pretende examinar la importancia real de los materiales de este periodo cultural para individualizar los yacimientos, reconocer diferencias y poder fechar los distintos procesos culturales, contrarrestando en la medida de lo posible la escasez de intervenciones arqueológicas desarrolladas en el ámbito de los siglos V y VIII.

Palabras clave: Saguntum, Época visigoda, Antigüedad tardía, Ciudad, Paisaje rural, Comercio.

\section{Abstract}

The discovery of material remains from the Visigothic period around Sagunto gives a glimpse of the little consideration towards the territory located halfway between the current provinces of Valencia and Tarragona. The aim of this paper is to examine the relevance of the vestiges from this cultural period in order to identify the features of these sites, analyse their differences and date the different cultural processes they have gone through, counteracting where possible the scarcity of archaeological research conducted in this field during the 5th and 8th centuries.

Keywords: Saguntum, Visigothic period, Late Antiquity, Town, Rural landscape, Trade. 


\section{SUMARIO}

1. Introducción. 2. Las evidencias arqueológicas de época tardía en Sagunto. 3. La ciudad de Sagunto. 4. El ámbito rural. 5. Los procesos de intercambio. 6. Conclusiones.

\section{INTRODUCCIÓN}

La ciudad de Sagunto ocupa un lugar relevante en el panorama general de la investigación de época ibérica e hispanorromana. El oppidum de Arse está localizado en el cerro del Castillo, en la vertiente meridional de la última estribación de la Sierra Calderona a $160 \mathrm{~m}$ sobre el nivel del mar. Las primeras evidencias arqueológicas de la población ibérica se han localizado en la cima occidental en el siglo VI a. C., pero hasta fines del siglo V o primeras décadas del IV a. C. no se atestigua la construcción de la cerca muraria en la ladera meridional. Por su parte, la cima más oriental está situada en medio del llano litoral y desde ella tempranamente se inicia el control del paso de la vía Heraclea, la posterior vía Augusta, así como la vía que discurre hacia el interior del valle del río Palancia y de la línea de costa que abarcaría prácticamente el territorio de la regio edetana. Sobre este cerro, a lo largo de la ocupación romana, se construyó el foro. En la primera mitad del siglo IV a. C. Sagunto ya era una gran ciudad de la que dependía el asentamiento costero del Grau Vell, establecimiento en el que cabe señalar la presencia de un volumen muy interesante de restos materiales desde el siglo $\mathrm{V}$ a. C. En la siguiente centuria hallazgos recientes han revelado una ocupación extramuros, tal y como indica la cerámica ibérica doméstica que salió a la luz en la excavación del solar de la Morería, en la parte baja de Sagunto (Ferrer, Oliver y Benedito 2016, 101; Ferrer, Benedito y Melchor 2018, 357-59).

El dominio romano sobre este enclave se intensificó desde que en el año 226 a. C. entró en vigor el conocido como Tratado del Ebro. Los textos clásicos mencionan la ciudad porque es escenario de enfrentamientos acaecidos en el marco del conflicto bélico desde el 218 a. C. Las citas de Polibio, Livio, Floro y Cornelio Nepote se remontan al episodio de asedio cartaginés (Polibio 3, 15; Polibio 3, 17, 6-7; Polibio 3, 17, 9-11; Polibio 3, 20; Livio 21, 6; Livio 21, 7, 10; Livio 21, 15, 1-2; Livio 21, 19, 9-11; Livio 21, 7, 4; Livio 21, 8, 3; Livio 21, 15, 3; Livio 21, 9, 2; Floro 1, 22, 3; Cornelio Nepote De vir. Ilustri, $42)^{1}$, que finalizó con la caída de la ciudad en el 219 a. C. Por su parte, los últimos años la arqueología saguntina se ha enriquecido con los hallazgos de nuevas excavaciones para el examen de información novedosa. Las noticias aportadas sobre la evolución y transformación de la ciudad han experimentado un cambio notable gracias a los restos que han salido a la luz en las excavaciones de la parte de la ciudad localizada junto al Palancia. Sabemos que, durante el Bajo Imperio, el urbanismo característico de la civitas romana se encuentra en fase de decadencia para paulatinamente abrir paso a un nuevo modelo urbano. En este sentido, las distintas intervenciones han permitido probar que existe una singular transformación de los edificios que destacaban por su representatividad pública y monumental y que la ciudad había construido desde el gobierno de Augusto, esto es algunos templos, plazas públicas, viales, etc. (Ferrer, Benedito y Melchor 2018, 363-71). Sin embargo, las fuentes escritas así como las propias investigaciones arqueológicas proporcionan datos que hoy en día son insuficientes para acometer el análisis completo del proceso de renovación que afectó a la ciudad de Sagunto y su territorio en época tardoantigua. Por ello, no es fácil valorar la verdadera importancia que tuvo dicha ciudad durante los últimos siglos de dominación romana y el control efectivo de los visigodos sobre la Península, es decir, entre mediados del siglo V y primeras décadas del siglo VIII. Por

1 Entre otras referencias romanas que describen la maniobra militar cartaginesa. 
otro lado, el estudio del material arqueológico de esta época que obra en poder de museos y de ciertas instituciones culturales presenta además el problema de las circunstancias en los que fueron recogidos, así como la falta de excavaciones sistemáticas que respondan a proyectos previos definidos, ya que la mayoría de los restos proceden de excavaciones que no se han publicado o de hallazgos casuales que fueron depositados a través de donaciones.

Con este panorama durante los últimos años ha resultado muy difícil siquiera sugerir un modelo teórico que explique los cambios de las pautas de poblamiento que tuvieron lugar en la zona desde la desaparición del imperio romano a la llegada del mundo propiamente medieval, si bien es posible conjeturar una cierta evolución a partir de la comparación con otras áreas próximas, como Valencia. En cambio, como veremos en el último de los apartados, gracias al estudio de estos materiales arqueológicos pueden conocerse relativamente bien determinados los aspectos socio-económicos y cómo estos evolucionan a lo largo de parte del periodo considerado visigodo.

El propósito de este artículo, en primer lugar, es describir la problemática que presenta el estudio de la época visigoda en estas tierras, reuniendo y analizando de forma crítica las principales aportaciones bibliográficas, e incluyendo la descripción de la cultura material y un conciso planteamiento de las perspectivas de futuro que ofrecen los materiales y los yacimientos donde estos se han localizado. El margen cronológico que estudiamos está relacionado con el aumento de la influencia y poder godos en la Península, esto es la segunda mitad del siglo V. A estas alturas, la protección de las provincias hispánicas dependía sobre todo de la comparecencia de tropas de foederati godos, que se hallaban divididas en el ámbito territorial de la Tarraconense y de la Bética. El contexto de esta situación está definido por nuevos acontecimientos: como la llegada en 456 de una expedición militar dirigida por el rey Teudorico II e iniciada en nombre del emperador Avito para acabar con la monarquía militar sueva de Requiario, la destitución y muerte del emperador ese mismo año y la restauración de la presencia militar goda del año 458. A ello se une la creación de una nueva coyuntura política en la que tendría amplia trascendencia el nombramiento de Arborio en el 461 al frente de la comitiva Hispaniarum por el propio Teuderico II, después de la deposición y ejecución del emperador Mayoriano en la ciudad ligur de Dertona, además de la proliferación de diferentes acciones contra otros pueblos en la Península. En el año 472 el rey Eurico atacó la Tarraconense, último reducto del poder romano, que tres años antes había roto con el poder imperial. Una nueva expedición bajo el mando del general godo Heldefredo y Vicencio se dirigió por la costa mediterránea en el 473 , tomó la emblemática base romana de Tarragona y siguiendo el trazado de la vía Augusta conquistaron las ciudades que hallaron a su paso (García 2017, 94). La lógica induce a pensar que entre estas ciudades estaría Sagunto y su puerto. En definitiva, el marco de estudio que planteamos comprende el periodo anterior a la derrota de los visigodos ante los francos en el 507, lo que obligó a trasladar la capital a Toledo y crear el reino visigodo en la antigua Hispania. La monarquía había unificado la Península sometiendo a suevos y expulsando a bizantinos que habían ocupado el sureste peninsular. Con la muerte de Wamba en el año 680, las luchas internas de la nobleza goda por ocupar el trono debilitaron el reino, circunstancia que facilitó la conquista árabe en el 711, fecha que define el momento final del presente trabajo.

Pero mientras una gran parte de la Comunidad Valenciana se ha convertido en uno de los mejores ejemplos para estudiar el periodo visigodo en el contexto peninsular, el conocimiento de Sagunto y su territorio continúa ofreciendo una pobre realidad en la investigación en beneficio de las fases anteriores de mayor monumentalidad edilicia. Para la época visigoda disponemos de estratigrafías arqueológicas fiables que 
proceden sobre todo de excavaciones urbanas realizadas en la ciudad de Valentia (Ribera 2003; 2005; 2008; Ribera y Rosselló 2000; 2009; 2019), Ilici (Guilabert, Ronda y Tendero 2019; Gutiérrez 2004; 2013; Lorenzo 2007; Poveda 2005; Ramos 1973; 1995), Edeta (Escrivà 2014; Escrivà, Martínez y Vidal 2005) o Allon (Espinosa, Ruiz y Marcos 2019). Del ámbito rural la información arqueológica proviene sobre todo de la villa romana de l'Horta Vella en el municipio de Bétera, la villa del Pla de Nadal (Ribera y Rosselló 2019) y el castrum fortificado de València la Vella, en Riba-roja de Túria (Jiménez y Burriel 2007; Burriel, Jiménez y Rosselló 2019; Huguet et al. 2019), la villa de Canyada Joana en Crevillente (Trelis 20112012; Lorenzo 2016), la Senda de l'Horteta en Alcàsser (Alapont y Tormo 2005; Martínez et al. 2018) o el Monastil de Elda (Poveda 2007). También de asentamientos costeros como els Banys de la Reina de Calpe (Ronda, Luján y Sevila 2018) o los restos arqueológicos del monasterio de Punta de l'Illa de Cullera (Rosselló 2000; 2019), y finalmente el edificio visigodo de els Casals del Mas de Sabater de Morella (De Antonio y Pérez 2019), entre otros muchos yacimientos.

Para el estudio de la ciudad de Valencia, la documentación escrita informa de la existencia de una sede episcopal conocida desde el siglo VI gracias a las firmas de prelados que asisten y suscriben los concilios nacionales y provinciales, inscripciones y el hallazgo de edificios de culto. Los testimonios historiográficos son abundantes, sabemos de la celebración el 4 de diciembre del 546 de un concilio provincial en la ciudad propiciado por Justiniano, que demuestra la consolidación de Valencia como sede episcopal (Ribera y Rosselló 2019, 69). En Valencia se han hallado cuatro inscripciones de época visigoda, tres de ellas dedicadas a obispos valentinos, Justiniano y Anesio, que documentan la construcción de edificios religiosos y la reconstrucción de los antiguos (Corell 1989, 64). Por su parte, la arqueología ha puesto al descubierto restos de uno de los grupos episcopales más sobresalientes y mejor conservados de la Península. A partir del siglo VI, la Iglesia se esfuerza en expresar una imagen de poder a través de la construcción de edificios, que se percibe especialmente con Justiniano, pues se ha querido ver en él al principal promotor del grupo episcopal asociado a la figura del mártir San Vicente. Posteriormente, el espacio de la plaza de l'Almoina se modifica para cambiar de nuevo bajo control visigótico, tal y como parece indicar la presencia de un doble episcopado católico y arriano entre las postrimerías del siglo VI y los primeros años del VII: Celsino y Ubiligisclo, respectivamente. De la Valentia de esta época, gracias a las excavaciones sabemos que se produce un fenómeno de desmantelamiento general representado por el expolio de materiales procedentes de antiguos edificios y el hallazgo de un gran número de vertederos repartidos por toda la ciudad. Por otro lado, el panorama urbano está definido por la proliferación de nuevas iglesias, como la de Roqueta, núcleo martirial que desarrollará una comunidad monástica a su alrededor, o la de la calle del Mar, basílica funeraria en relación a un cementerio extramuros. En la plaza del Negrito se recuperaron pies de altar y otras piezas litúrgicas, tal vez procedentes de una iglesia cercana (Ribera 2008, 307).

Desde el descubrimiento de la basílica paleocristiana en 1905 en la ciudad de Ilici se han efectuado distintas propuestas de datación de los restos, que varían del siglo IV al VI. Los trabajos que llevó a cabo A. Ramos permitieron descubrir dos necrópolis intramuros, una de ellas ad sanctos. Sobre la antigüedad de la sede episcopal ilicitana, cuyos representantes no conocemos hasta el siglo VI, no es mucho lo que sabemos. Se ha apuntado que a partir de la conquista visigoda, sus obispos participaron en los concilios de Toledo hasta los últimos conocidos durante todo el siglo VII. Ilici había formado parte de la Spania bizantina hasta la conquista visigoda de Carthago Spartaria (Lorenzo 2007; 2016). Respecto al territorio ilicitano, algunas de las villae muestran un momento de esplendor constructivo a partir 
del siglo IV, pero se abandonaron a partir del V. Hasta esta centuria el Portus Ilicitanus concentró las importaciones marítimas. En cualquier caso, se han encontrado restos que apuntan a la continuidad poblacional en esta zona que se prolongaría hasta más allá de la dominación bizantina.

En Edeta, hacia mediados del siglo VI, coincidiendo con el reinado de Theudis (531548) y el pontificado del obispo Justiniano, se aprecian los primeros indicios de reutilización del antiguo santuario oracular altoimperial localizado en la partida de Mura. Todo el complejo continuó en uso hasta un momento avanzado del siglo $\mathrm{V}$, cuando el caldarium de las Termas Menores, de planta basilical con el ábside orientado al Este, pudo haber funcionado como iglesia cristiana, ya que en la fachada principal se excavaron dos tumbas de este periodo registrándose varias piezas de uso litúrgico. A partir del siglo VI, se ha sugerido que este edificio se convirtió en monasterio cristiano. En todo el conjunto se han encontrado sepulturas individuales y cuatro tumbas formadas por losas, que presentan entre siete y nueve muertos cada una. El hallazgo de ciertos objetos de origen oriental vinculados a la religión copta, como una lámpara con la representación de una cruz, del siglo VI, procedente de la actual Turquía, o el pasador de cinturón con decoración de pantera, fechado en el VII, han servido para datar el conjunto cristiano de Edeta. La mayor parte de los edificios fueron abandonados durante esta centuria debido a que la población cambió el emplazamiento a la actual Vila Vella de Llíria. Finalmente, en época islámica la zona se transformó en campos de cultivo (Escrivà 2014, 123-42).

\section{LAS EVIDENCIAS ARQUEOLÓGICAS DE ÉPOCA TARDía EN SAgUNTO}

Analizados estos precedentes, pretendemos describir las evidencias materiales que definen la existencia de ciertas características de la ocupación de este territorio entre mediados del siglo V y primeras décadas del VIII. Para ello analizaremos los restos muebles e inmuebles que se han documentado y los conjugaremos con una propuesta de investigación centrada en la justificación de las evidencias de edificios o elementos propios del periodo visigodo. Por último, reflexionaremos acerca de la pretendida ausencia/presencia de niveles arqueológicos de esta época en el territorio y en algunos casos en Sagunto, pues la Antigüedad tardía está escasamente documentada por los hallazgos de monedas, cerámica, inscripciones, materiales de construcción, etc. Pero, como se ha comentado anteriormente, la mayor parte de la información o no se ha publicado o no la proporcionan excavaciones metódicas, sino que se han recuperado de hallazgos antiguos.

\section{La CiUdad de Sagunto}

En las publicaciones es frecuente constatar un largo paréntesis entre la ocupación del Bajo Imperio y el periodo musulmán, lo que a veces ha conducido a realizar consideraciones confusas o imprecisas sobre el verdadero carácter de este periodo histórico, deduciendo la ruina y abandono de la ciudad romana hasta prácticamente la ocupación musulmana. Entendemos, sin embargo, que algunos de los espacios que habían sido el motor de la ciudad entre el Alto y el Bajo Imperio, experimentan una gran transformación desde la Antigüedad tardía. Este nuevo esquema urbano dejaría deshabitada la parte baja de Sagunto (Ferrer, Benedito y Melchor 2018, 372-74). Pero solo unos siglos más tarde, la madina Murbātir se abrió paso como una de las medinas más relevantes de la zona. En este territorio fue un destacado foco religioso, económico, comercial y una importante plaza con marcado carácter estratégico, gracias a su ubicación en lo alto del cerro y al lienzo amurallado que había sido reconstruido. No se sabe con certeza cuándo las huestes de Jaume I se hicieron con el control de la ciudad ya que son escasas las noticias que se tienen. La madina pudo capitular entre 1236 y 1237, antes del sitio y conquista de Balansiya 
a partir de 1238 (López et al. 2014, 242; Guinot 2007).

En realidad, la incidencia de algunas intervenciones arqueológicas ha tenido como resultado el hallazgo de materiales visigodos tanto en el recinto urbano como en sus alrededores, que en algunos casos nos permiten establecer la continuidad a lo largo de la tardoantigüedad hasta la alta Edad Media. Hoy en día, es imposible describir un panorama algo más preciso sobre el poblamiento en el interior de la ciudad, pues efectivamente se constatan amplias extensiones extraurbanas vacías desde finales del siglo IV, pero también hay que hacer hincapié en la persistencia de la ocupación en ciertas áreas diseminadas de las que en un futuro se podrán deducir algunos patrones. Por otro lado, las murallas debieron ser uno de los elementos urbanos que suscitarían mayor interés y preocupación por su mantenimiento y conservación (Fig. 1).

El Grau Vell fue uno de los puntos de atraque más importantes de la costa valenciana y la principal infraestructura portuaria de la zona entre los siglos $\mathrm{V}$ a. C. y posiblemente hasta principios del siglo VI de nuestra Era, momento en que entró en decadencia seguramente por el declive general de la ciudad o tal vez también consecuencia de algún proceso natural, como un hipotético cegamiento de la dársena del puerto (Járrega 2011, 523). Fue durante todo el periodo romano uno de los portus principales en los circuitos mediterráneos y peninsulares, junto a Tarraco, Emporion, Carthago Nova y Gades. Las excavaciones realizadas en el puerto han puesto de relieve la existencia a lo largo de la época tardorromana de un trazado urbano con habitaciones y calles enlosadas (López 1991, 98-102). Sabemos que el

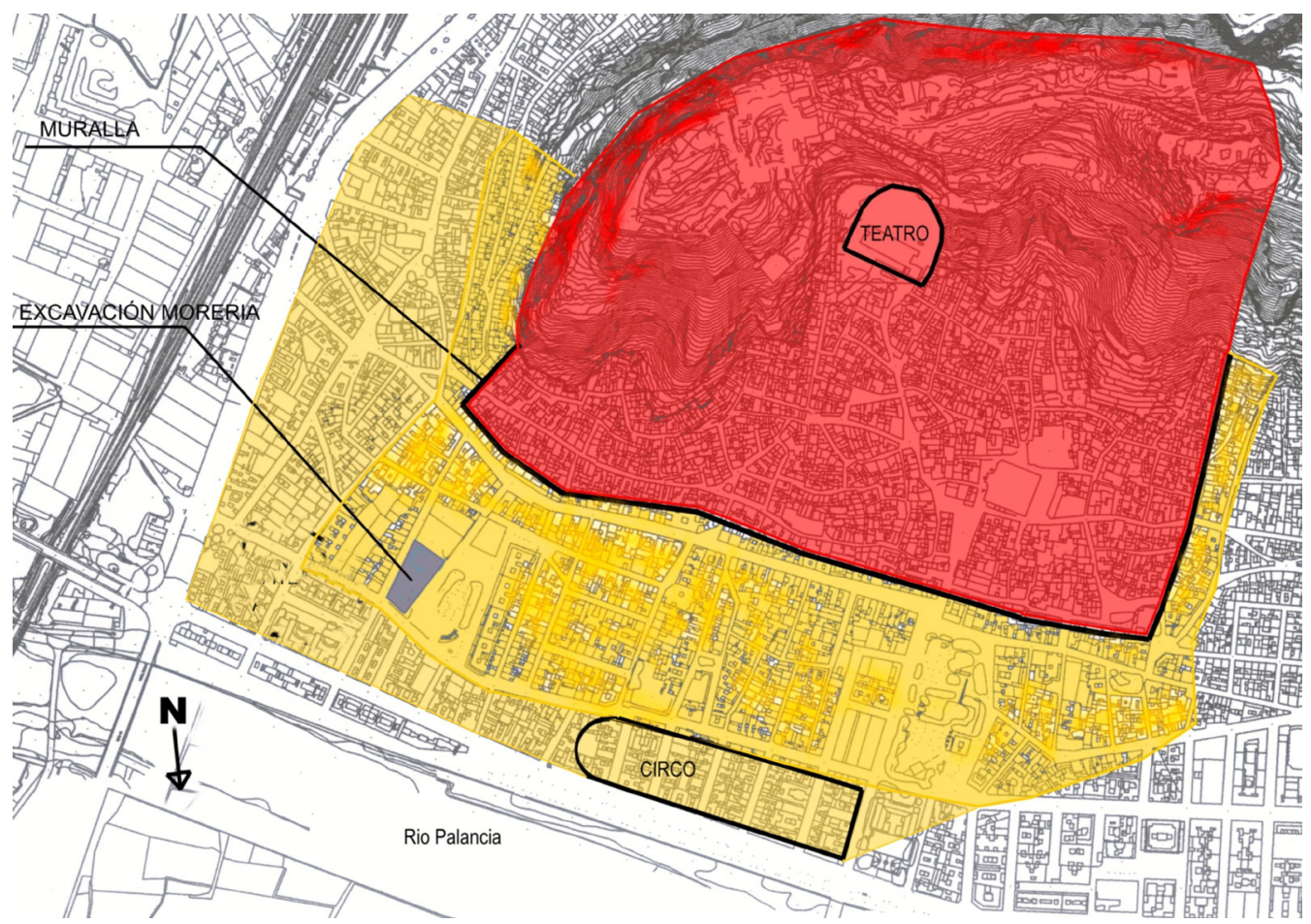

Figura 1. Plano de la ciudad de Sagunto. Trama de color rojo: propuesta del espacio urbano en época visigoda dentro del perímetro amurallado. Trama de color amarillo: restos de la ciudad extramuros en época altoimperial. Ilustración: autores. 
comercio continuó activo en esta época, pues se han documentado importaciones africanas y en el siglo $\mathrm{V}$ se ha estudiado la llegada de productos procedentes de la Galia. También se han encontrado materiales característicos del norte de la Meseta (Aranegui 2004; Benedito 2013). En efecto, el puerto continuó activo durante la tardoantigüedad, y así lo relacionan los intercambios realizados con asentamientos del territorio de Saguntum como l'Horta Seca, Sant Josep (ambos en la Vall d'Uixó) y el Castellar (Xilxes) (Arasa 2000, 113-18; Járrega 2011, 556).

Respecto a la ciudad, apenas existe información concreta sobre el periodo visigodo procedente de excavaciones, aunque, como se ha comentado, quizá debamos atribuir esa carencia a la escasez de publicaciones sobre la cultura material de esta época. En este sentido, los resultados preliminares de un estudio que estamos llevando a cabo desde la Universitat Jaume I sobre cerámicas todavía inéditas que fueron recuperadas en las laderas del cerro del castillo, apuntan a una cronología del siglo V o quizá del VI. Las únicas referencias sobre niveles visigodos describen la existencia de estratos de colmatación constituidos por tegulae, imbrices, terra sigillata Africana A, C y $\mathrm{D}$, junto a cerámica africana común forma Hayes 197, Hayes 181 y Ostia I, que aparecieron sobre estructuras bajo imperiales en las excavaciones de la iglesia de San Salvador. Su excavador, I. Hortelano, ha atribuido a estos restos una cronología que sitúa entre fines del siglo IV y mediados del siglo V (Hortelano 1992, 56), aunque quizá puedan abarcar toda esta centuria.

La intervención que hasta el momento aporta más información arqueológica sobre la ciudad es la realizada en el solar de la Morería. Este solar se localiza en la parte baja de Sagunto, junto al río Palancia. Los trabajos de campo se hicieron entre los años 2002 y 2005 sobre una superficie de $1.700 \mathrm{~m}^{2}$, y aportaron una visión muy interesante sobre el incipiente urbanismo de época ibérica, tumbas tardorrepublicanas, templos, un arco honorífico y una calzada porticada de $60 \mathrm{~m}$ de longitud, estos últimos de época imperial (Ferrer, Benedito y Melchor 2018, 371-72). Respecto al periodo visigodo se registraron dos fases: la primera de ellas corresponde al siglo $\mathrm{V}$ y está relacionada con el saqueo de las estructuras de época romana que se dio tras el abandono de esta parte de la ciudad. Durante las primeras campañas aparecieron derrumbes de ladrillos sobre la calzada, restos de extracción de pavimentos de opus signinum, sillares o vestigios de bloques procedentes del arco honorífico que se levantó junto al templo, junto a una gran cantidad de materiales desechados que amortizaban los últimos niveles de ocupación del vial. Estos niveles hacen referencia a un saqueo programado de materiales constructivos, que pudo finalizar con la reconstrucción de otras edificaciones y probablemente la cinta muraria de la ciudad, cuyo trazado se ha localizado en la calle Camí Real, a escasos metros de este punto. Por otro lado, durante el proceso de excavación los pilares del pórtico occidental se hallaron casi intactos, mientras que los del lado oriental habían desaparecido prácticamente hasta la base y otros se habían abandonado en distintos tramos de la calle (Fig. 2).

La siguiente fase se ha puesto en relación con la extracción de materiales que arrasaron parte de las estructuras romanas hasta la base de cimentación, periodo que se extendería entre el siglo $\mathrm{V}$ y los primeros siglos de ocupación musulmana. Las fosas se rellenaron en época andalusí con el objeto de terraplenar este espacio y poder utilizarlo como vivienda. Los hallazgos de época visigoda se completaron con la excavación de un enterramiento familiar en el interior de un tramo de la cloaca de la calzada romana, que estaría posiblemente asociado a una arquitectura construida con cantos de río y mortero sobre la misma después de que este sector de la ciudad se hubiera abandonado. Los enterramientos presentaban huellas de muerte violenta y correspondían a dos adultos, hombre y mujer, y dos jóvenes. La cronología se ha fijado en torno al siglo VI (Polo y García-Prósper 2005, 225). Los restos de la construcción se 

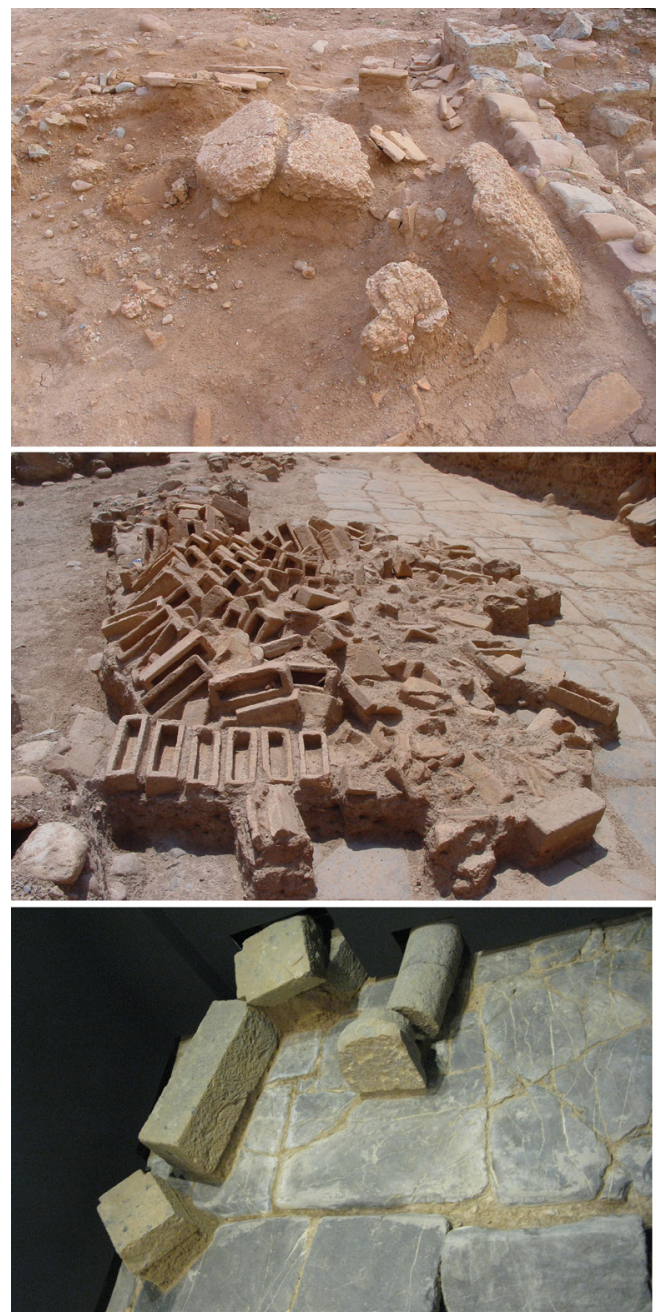

Figura 2. (1) Pavimentos de opus signinum desechados en una de las estancias del espacio de la domus bajoimperial. (2) Derrumbe de ladrillos localizado en el flanco septentrional de la calzada. (3) Pilar y columna del pórtico occidental documentados sobre la calzada enlosada. Fotos: autores.

localizaron $2 \mathrm{~m}$ al sur de los enterramientos y conformaban tres estancias cuadrangulares que, por las dimensiones, formarían parte de una probable arquitectura funeraria. Con todo, no es seguro, por el momento, atribuir ésta u otras funciones a los restos, pues no se excavó en su totalidad debido a que se prolongaba fuera del solar excavado (Fig. 3 y 4 ).

Respecto a las investigaciones llevadas a cabo en el solar de la Morería, Járrega recientemente ha documentado un fragmento de borde de ánfora vinaria de la forma Late Roman Amphora 4, que se producía en la zona de Gaza, Palestina, entre los siglos V y VI (Járrega e.p.).

Por último, se deben referenciar los tremises de oro que se acuñaron en la ceca saguntina durante el reinado de Gundemaro (610-612) y Sisebuto (612-621). En los últimos años han ido surgiendo estudios muy diferentes sobre este hallazgo. Por un lado, las acuñaciones se han relacionado con la captura de la ciudad de Sagontia en el 603 por parte de soldados imperiales (milites quosdam Sagontia per duces obtibuit), que debió significar el desguarnecimiento bizantino de la ciudad y la ocupación por fuerzas godas. Lo que ha servido para explicar la presencia de una guarnición goda probablemente procedente de Recópolis, que al poco tiempo se retiró de la ciudad, como indica el cese de la actividad acuñadora tras Sisebuto (López 2009, 182-83). Sin embargo, no todos han aceptado el hecho de identificar Sagontia con Sagunto. Otros han defendido que la acuñación de estas monedas tuvo lugar en cecas que se instalaron, como en Sagunto, en ciudades distribuidas a lo largo de la vía Augusta. Los tremises de oro, por su elevado valor, debieron tener una circulación puntual entre la corte imperial goda y los nobles, o quizá hacia el extranjero, no lo sabemos. La sociedad visigoda, especialmente la rural, no estaba monetizada, solo se acuñaba moneda de oro, por lo que la población utilizaba las antiguas monedas de bronce romanas o realizaba pagos en especie (Pliego 2008, 133-34).(Fig. 5)

\section{EL Ámbito RURAL}

En el estado actual de la investigación no sabemos con exactitud la superficie que debía administrar la ciudad de Sagunto en momentos tardíos, ni puede asegurarse el grado de mantenimiento o modificación que pudo experimentar el área jurídica y económica del antiguo territorium de época romana. Por lo que no podemos asegurar que se diera una 


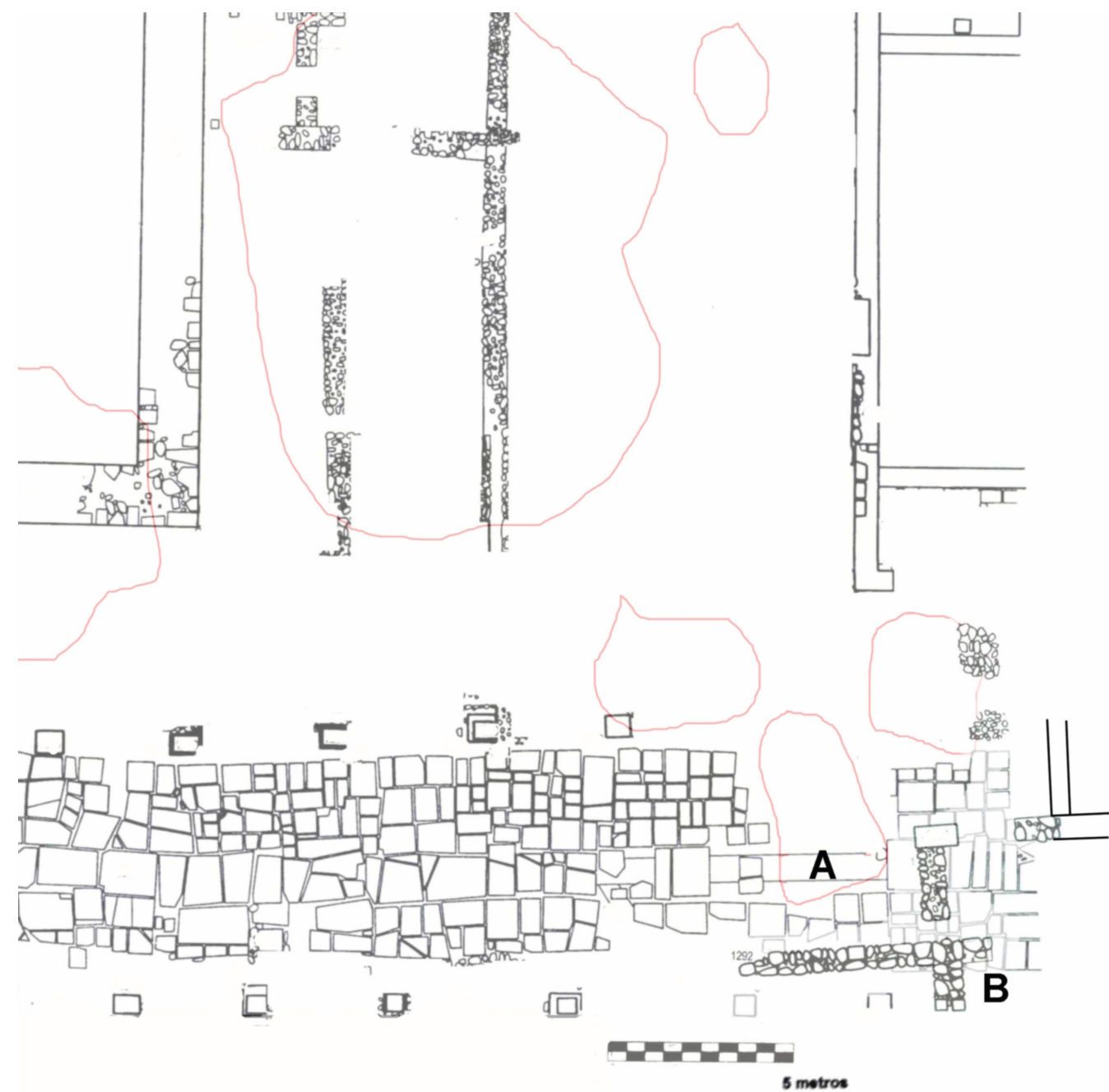

Figura 3. Plano de la excavación del solar de la Morería con los restos de época visigoda y delimitación de las fosas de saqueo de materiales. (A) Enterramientos localizados en el interior de la cloaca. (B) Cimentaciones de muro mampuesto relacionadas con las inhumaciones. Ilustración: autores.

ampliación o reducción del suelo que durante el Alto Imperio debía incluir la comarca del Camp de Morvedre, las poblaciones de Puçol y El Puig en la comarca valenciana de l'Horta Nord, los territorios castellonenses de la Plana Baixa y los núcleos de Borriol y Castellón de la Plana en la comarca de la Plana Alta (Arasa 2000, 113-18; Járrega 2011, 435-36). En el 298 se promulgó la nueva división provincial del emperador Diocleciano, pero el límite entre la Tarraconensis y la Carthaginiensis no está claro, pese a que Valentia se encontraba dentro de esta última. No se puede afirmar que corresponda a la antigua división en conventos jurídicos del Alto Imperio y como no aparece referenciado en ningún documento escrito, se ha sugerido que podría estar en el río Millars (Mansilla 1959), el Palancia o quizá la Serra d'Espadà. Albertini lo sitúa en Almenara basándose en el límite episcopal tortosino (Albertini 1923). Pero el hecho de que tanto los territorios septentrionales como los más 

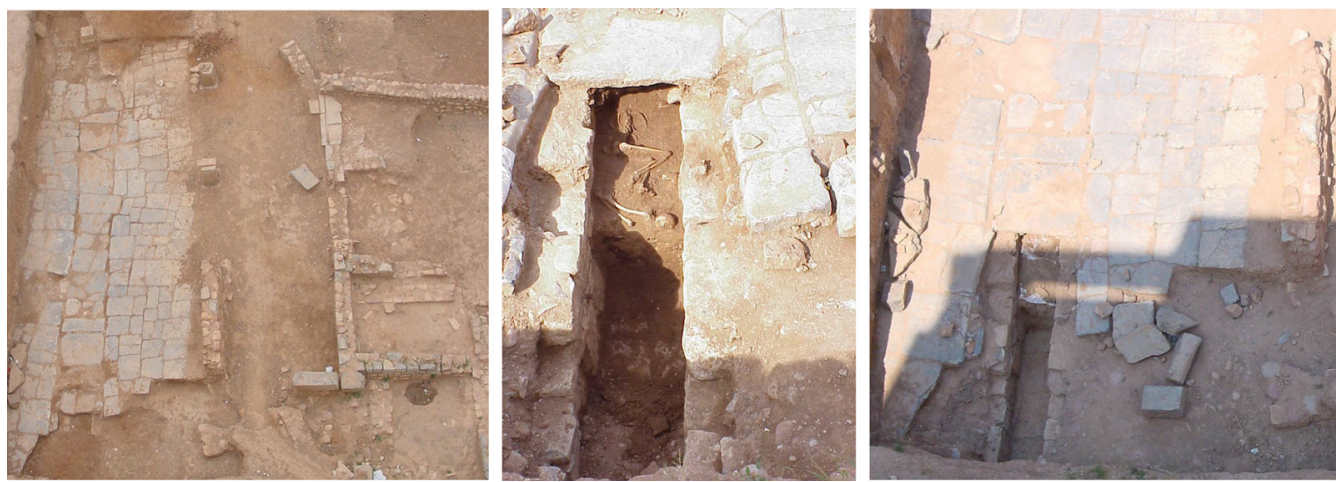

Figura 4. (1) Calzada del solar de la Morería. (2 y 3) Detalle de la cloaca con los enterramientos. Foto: autores.

meridionales quedaran alejados de las sedes episcopales circundantes, esto es Tortosa y Valencia, permite plantear la posibilidad de que Sagunto pudo ser una zona fronteriza dirigida a racionalizar la administración de un amplio territorio, pues, como se ha citado, su emplazamiento reunía unas excelentes condiciones estratégicas junto a importantes vías de comunicación.

En este apartado debemos hacer mención a los asentamientos tardorromanos, mayoritariamente villae, que presentan una amplia pervivencia, de los que muy pocos han sido excavados o publicados durante los últimos años como para poder determinar con precisión su evolución. Pero solo algunas excavaciones arqueológicas han permitido estudiar el desarrollo de las explotaciones en el territorio de Sagunto desde finales del siglo I a. C. y sobre todo durante la centuria siguiente, hasta la época tardorromana, como por ejemplo en Benicató, en la localidad de Nules, uno de los ejemplos de villa más completos que conocemos en la provincia de Castellón. Las primeras noticias sobre la aparición de restos arqueológicos en este yacimiento son una serie de hallazgos fortuitos que tuvieron lugar en el siglo XIX en un espacio entonces conocido como Pujol de Benicató. La villa se dio a conocer en 1883, pero los descubrimientos más relevantes se realizaron en 1955 cuando un tractor sacó a la luz teselas de mosaico y fragmentos de

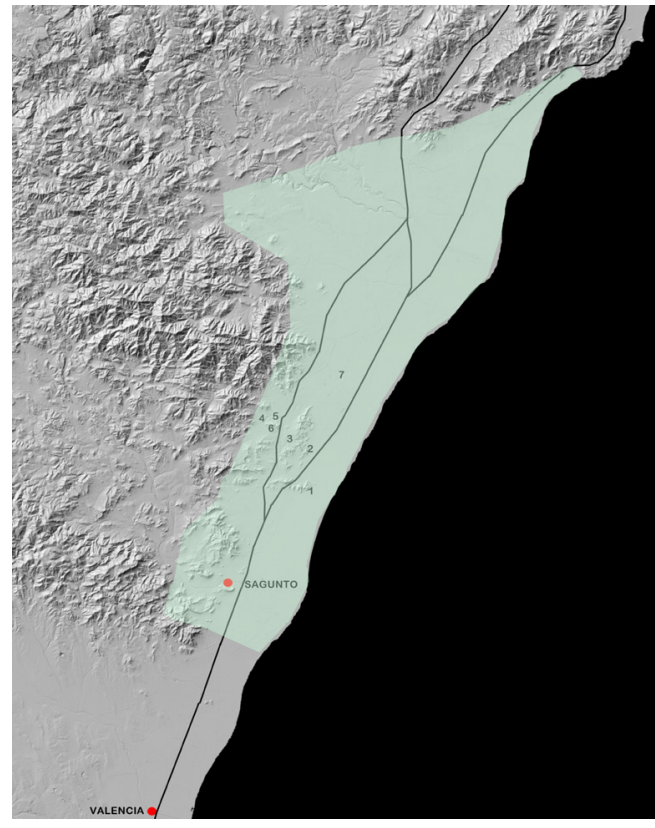

Figura 5. Principales yacimientos citados en el texto y vías de comunicación paralelas a la costa. Trama verde: propuesta de delimitación del territorio de Sagunto en época romana. Muntanyeta dels Estanys (1); el Castellar (2); l'Horta Seca (3); Sant Josep (4); Necrópolis de la Unión (5); Muntanyeta de la Cova (6); Benicató (7).

otras estructuras. Las excavaciones fueron realizadas en una parcela de $2.500 \mathrm{~m}^{2}$. En la villa las estancias alto imperiales están dispuestas alrededor de un peristilo. La pars urbana se adornó con pavimentos musivos y poseía unos baños, mientras que en la pars rustica se encontraron los restos de un posible 
torcularium (Gusi y Olaria 1977, 103-05). También se han registrado fragmentos de sigillata africana D de la forma Hayes 99 y del estilo decorativo E de la tipología de Hayes, que ofrecen una cronología situada en pleno siglo VI y cerámicas con motivos cristianos. El primer ejemplar es un fondo de cerámica africana clara $\mathrm{D}$, con la representación de un personaje religioso. Se trata de un hombre con el torso desnudo y apoyado en un cayado. La segunda pieza corresponde a otra cerámica africana con una cruz gemmata impresa (Benedito 2015, 135) (Fig. 9.5 y 9.6). Por otro lado, se hallaron en Benicató tres epígrafes, uno de ellos es funerario y presenta una lectura imprecisa debido a su estado de fragmentación y a que fue encontrada fuera de cualquier contexto arqueológico. Algunos autores lo clasifican como una inscripción cristiana de los siglos VI-VII. Se trata del fragmento inferior izquierdo de una inscripción sobre piedra caliza de escritura incisa, tosca e irregular alineada a la izquierda con el texto [- - - - - \} / Vess[- - ] / Natạ[lis ?] / Qau[- - -] / Gracia[nus ?] (HEp 12, 125; Corell 2002, 486) (Fig. 8.4).

En el resto de la comarca de la Plana Baixa los yacimientos de esta época son menos conocidos pues apenas se han realizado trabajos arqueológicos. En las proximidades de Benicató, también en Nules, está el yacimiento de Camí Nou, donde se han excavado varias estructuras de época romana. En este lugar se halló también una inscripción cristiana que apareció sin embargo encastrada en una tapia contemporánea. Proporciona una fecha, el año 512, y una referencia a Jesucristo que para Corell conmemoraría la dedicación de una capilla cristiana (Corell 2002, 809-11). Otros autores la asocian a la villa de Benicató y a la construcción de una basílica de época visigoda en este lugar. Los propietarios de la villa debieron ser los fundadores de la capilla (Járrega 2011, 347). Con todo, los epígrafes son fragmentarios y presentan una interpretación incierta. La última inscripción está realizada en piedra calcárea de color negro y resulta atípica por lo que la lectura es insegura debido a la brevedad del texto conservado, que quizá podría pertenecer a una época posterior. Corell restituyó el texto: (alpha) Îhi(su)s (crux graeca) - / in e(ra) DL (crux graeca); donde la " $Y$ " integrada con la cruz representaría el nombre de Christus (Corell 2002, 609-11 no 488).

Los indicios de villae en la provincia de Castellón que perduran hasta la antigüedad son verdaderamente escasos. El yacimiento de l'Horta Seca, en la Vall d'Uixó, se ha relacionado con una cronología tardorrepublicana por el hallazgo de un pavimento musivario elaborado con opus signinum localizado en una de las estancias del balneum y de material ibérico. Sin embargo, no podemos saber si esta villa pudo tener un origen en el siglo I a. C. o si es ya de época imperial. Durante los trabajos también se encontraron vestigios arqueológicos de un torcularium que se han relacionado con la producción de vino. Sabemos que la villa fue abandonada en el siglo III, pero durante la excavación también se registraron fragmentos cerámicos de la forma Hayes 99 de sigillata africana D que se han fechado en pleno siglo VI (Járrega 2011, 289-90).

Junto a estos hábitats en el llano, se han documentado vestigios de un reducido número de yacimientos construidos en altura, como el poblado de Sant Josep y la Muntanyeta de la Cova, ambos en el término municipal de la Vall d'Uixó, el Castellar de Xilxes o la villa dels Estanys de Almenara, que no podemos considerar villae rústicas. En todos ellos se han identificado niveles arqueológicos de época ibérica que no perduran más allá del siglo I de nuestra Era. La ocupación romana en Sant Josep no se evidencia hasta la primera mitad del siglo IV. Respecto al Castellar de Xilxes también remite a la época tardoantigua, sin relación manifiesta con el asentamiento ibérico que se ha evidenciado en este mismo enclave.

El poblado de Sant Josep es uno de los más representativos de época tardorromana. Los hallazgos fueron estudiados por M. Rosas (1980, 291-93; 1984, 247-73), entre ellos más de 70 monedas, la mayoría de las cuales Ripollès las ha fechado entre los años 378 y 395 
(Ripollès 1980,211-15). También se documentó material óseo y metálico muy significativo, como los broches de cinturón de bronce de la familia delfiniforme que aparecieron en el poblado junto a una funda y puñales de bronce de tipo "Simancas" (Fig. 9.3). Piezas que evidencian relaciones comerciales con la Meseta y el curso alto del Ebro. La ocupación tardorromana se ha fechado entre fines del siglo IV y primera mitad del siglo V, momento en que se ocuparían algunas habitaciones de la parte alta (Rosas 1997, 1161-68). Con todo, pese a que se han atribuido al yacimiento ciertas funciones militares, hoy en día se ignoran sus características, pues no se han excavado estructuras arquitectónicas propias de este periodo. Por otro lado, también se han registrado fragmentos de ánforas de la forma Keay 62 que apuntan a una datación propia del siglo VI (Járrega 2011, 298). En el poblado, procedente de la excavación de M. Brugal, se encontró una pieza de arnés de equino en forma de hoja de hiedra o corazón decorado con incisiones y calados que dan lugar a un artístico lábaro, círculos concéntricos y otros motivos geométricos (Fig. 9.1). Esta pieza fue estudiada por M. Rosas y reestudiada años después por Aurrecoechea (2007, 321-44).

El poblado de la Muntanyeta de la Cova está localizado junto al río Belcaire, también en la Vall d'Uixó. Debido a la orografía del terreno, R. Járrega le ha otorgado un cierto carácter defensivo o de control militar (Járrega 2011, 295). Junto al poblado se halló una necrópolis que se ha datado entre los siglos $\mathrm{V}$ y VII, en la que salieron a la luz 65 inhumaciones que aparecieron repartidas en ocho estructuras funerarias elaboradas con grandes lajas de piedra caliza (Rovira 1993, 221-29). Sin embargo, los escasos materiales que se conocen corresponden a la época bajoimperial. Se trata de fragmentos de ánfora y sigillata africana $\mathrm{D}$, por lo que se duda de la adscripción visigoda de los enterramientos (Járrega 2011, 295).

El Castellar de Xilxes es un yacimiento ibero que tiene una fase tardorromana. Los materiales que se han encontrado, se han fechado a fines del siglo IV y durante la centuria siguiente. También se registró un solo fragmento de sigillata africana D de la forma Hayes 99, que remite a una cronología de pleno siglo VI (Járrega 2011, 311).

La Muntanyeta dels Estanys está localizada en Almenara. Este yacimiento fue descubierto por Pla y Cabrera a fines del siglo XVIII, pero no se realizaron excavaciones hasta 1949 cuando las investigaciones de Alcina darían a conocer la primera ocupación de época iberorromana (Alcina 1950, 92-128). Podría tratarse de una villa que se extendía a los pies de la elevación costera, con necrópolis monumental en la cima y vertiente meridional, mientras que la zona residencial se hallaría en la parte baja junto al cerro (Arasa 1999; Járrega 2011, 323-25). Los restos se han visto alterados por reocupaciones medievales, rebuscas clandestinas y una cantera de áridos. Con todo, Arasa defiende una singular interpretación del "edificio A", una de las construcciones localizadas en la cima oeste (Fig. 6). La arquitectura estaba orientada al Noroeste y tenía una planta rectangular de $9 \mathrm{~m}$ de longitud, 7,7 $\mathrm{m}$ de anchura, ábside central que le daba una longitud de 10,8 m y una disposición simétrica con el interior distribuido en tres naves (Alcina 1950, 103). El pavimento apareció a una cota de profundidad de $30 \mathrm{~cm}$. Los muros estaban enlucidos con estuco y presentaban restos de pintura de color verde y rojo. La excavación de la "sala B" proporcionó fragmentos cerámicos de asas de cinta, bordes, bases y cuellos con acanalados que fueron considerados medievales (Arasa 1999, 335). También se encontraron lateres, tegulae e imbrices con digitaciones que en algunos casos formaban bloques con argamasa que se consideró que procedían del tejado de la construcción. Tras realizar la excavación, por la orientación del edificio y el diseño de la planta se identificó como una ermita o capilla medieval (Alcina 1950, 104).

En la actualidad, la cima ha sido destruida casi en su totalidad y sólo queda una pequeña zona localizada en los límites de la cantera con dos muros que forman un ángulo recto, 
construidos con piedras irregulares y algún sillar trabado con mortero, junto a dos bloques de piedra calcárea sueltos que presentan muescas profundas. En la década de 1980 se justificó que podía tratarse de un edificio religioso o funerario de cronología tardía (Pérez 1985, 167). Estas mismas concepciones fueron asumidas por Arasa y tras estudiar las iglesias paleocristianas hispánicas con estructura tripartita y ábside, defendió que el "edificio A" podría encajar en esta tipología de edificios de culto cristianos. Por otro lado, en la zona del Estany se recuperó, fuera de cualquier contexto arqueológico, un fragmento epigráfico con la terminación -tor que Gimeno interpretó que podía hacer referencia a ciertos oficios (Gimeno 1988), mientras que Arasa propuso la lectura de uiator o lector, sugiriendo que se trataría de un edificio de culto eucarístico del siglo VI (Arasa 1999, 335-36).

La Unión es una necrópolis visigoda localizada dentro del núcleo urbano de la Vall d'Uixó. Se trata del único yacimiento arqueológico de la zona con restos visigodos que han sido excavados con metodología científica. Los trabajos se llevaron a cabo en 1993 pero hasta el momento solo se han publicado estudios paleopatológicos sobre alteraciones dentales (Gil et al. 1996, 106; Miquel et al. 1997, 351-56), breves referencias sobre el yacimiento (Gusi, Fernández y Fernández 2008 , 174) e información general que aparece recogida en la página web de la Asociación Arqueológica de la localidad ${ }^{2}$, por lo que, pese a la importancia de la excavación, tenemos un conocimiento ocasional de los restos descubiertos. Las noticias describen el hallazgo de 9 tumbas en cuyo interior se localizaron 66 individuos de diferentes edades y sexos. Las fosas medían entre 2,5 y $3 \mathrm{~m}$ y estaban delimitadas por grandes lajas de piedra caliza (Fig. 7). Tras realizar el análisis antropológico de las inhumaciones se documentaron lesiones traumáticas que habían sido producidas por

2 https://associacioarqueologicalavall. org/2017/03/12/necropolis-visigoda-una-vendettaprefeudal/. Fecha de consulta: 20/04/2020. objetos punzantes y cortantes. Con todo, algunos cadáveres mostraban síntomas de curación de las lesiones. También se recuperaron ajuares y según se desprende de algunas notas de prensa, en el yacimiento se han hallado más enterramientos ${ }^{3}$. En la actualidad, el Ayuntamiento de la localidad ha llevado a cabo una actuación de puesta en valor de la necrópolis. Se ha limpiado y adecuado, retirando la arena y colocando grava blanca, además se ha instalado un panel informativo y se han reconstruido las tumbas.

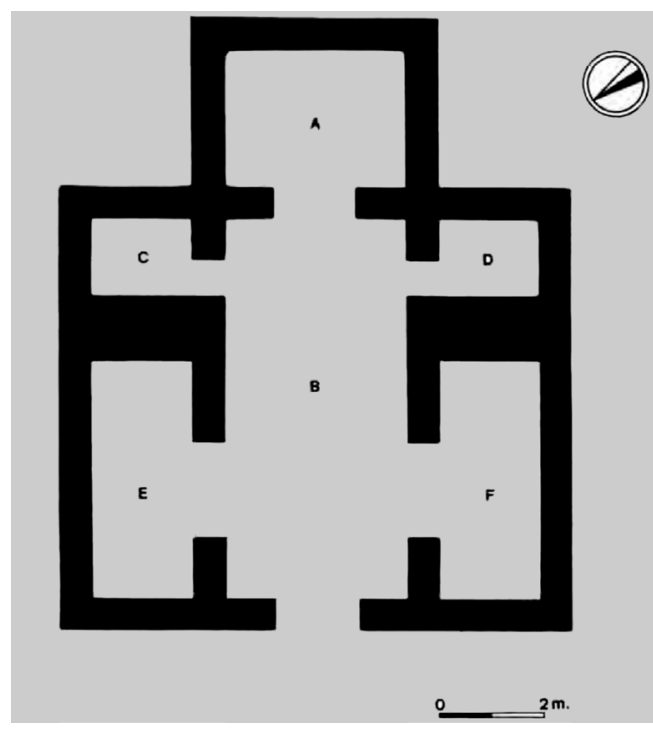

Figura 6. Planta del denominado "edificio A" de la Muntanyeta dels Estanys. Fuente: Alcina 1950.

Por otro lado, según se desprende de los resultados de las excavaciones realizadas inmediatamente al norte del territorio de Sagunto, en la llanura litoral de Cabanes, parece revitalizarse el poblamiento en el siglo VI, pues la excavación de los yacimientos del Brosseral y el Tancat han proporcionado restos arquitectónicos de esta época (Arasa y Flors 2009, 527). Mientras que en yacimiento del Sitjar Baix, en el margen norte del río Millars, en Onda, además de restos ibéricos e islámicos, se han encontrado estructuras construidas

3 http://www.castelloninformacion.com/la-vallduixo-necropolis-union/. Fecha de consulta: 21/04/2020. 

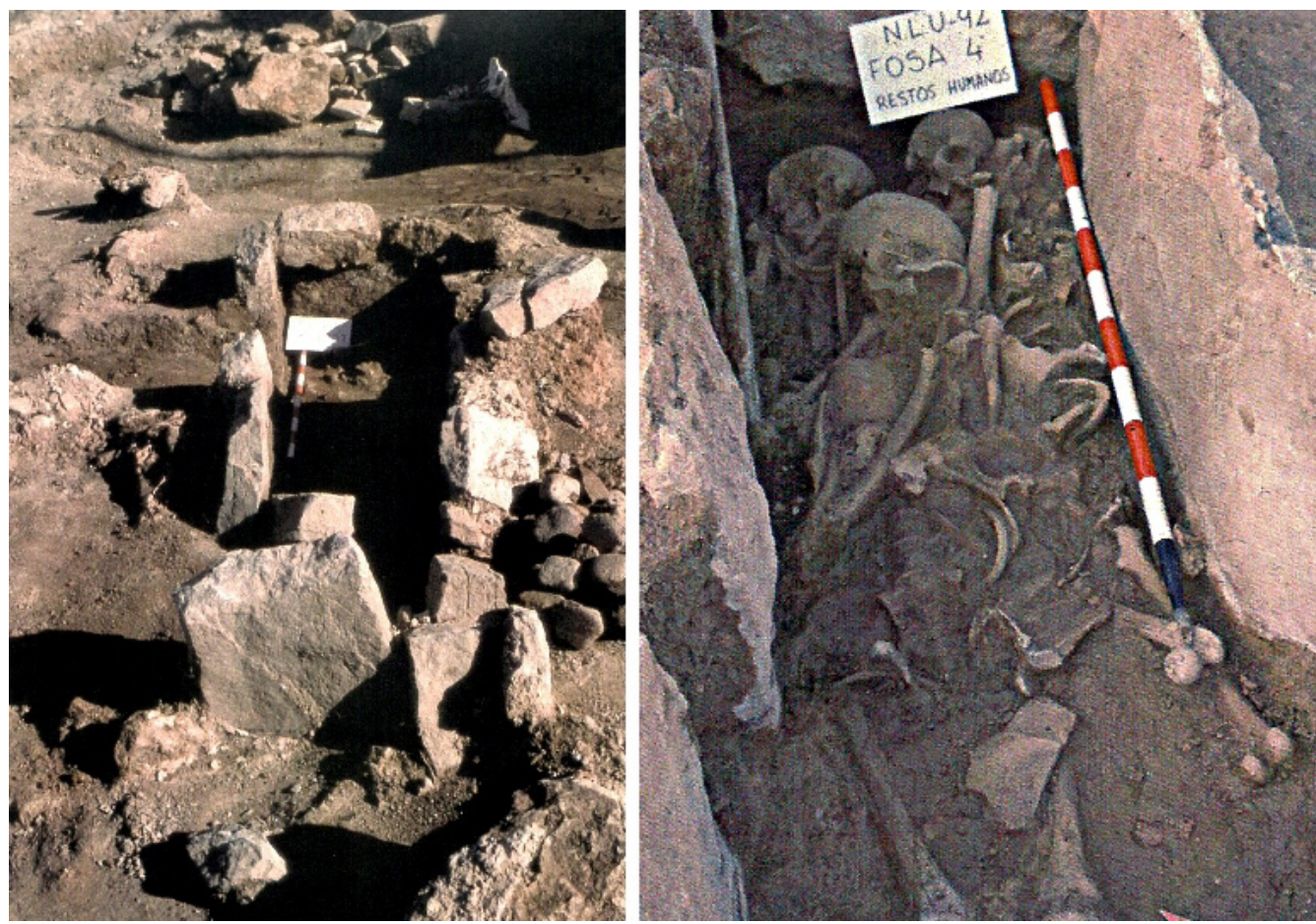

Figura 7. Proceso de excavación de una de las tumbas, necrópolis de La Unión, la Vall d’Uixó. Fuente: Asociación Arqueológica de la Vall d’Uixó.

con grandes mampuestos y niveles de la Antigüedad tardía, con abundante presencia de cenizas quizá relacionadas con loci sordentes o vertederos (Berrocal et al. 20042005, 394). Supuestamente en esta localidad fue encontrada una patena litúrgica de bronce fechada en el siglo VII que, sin embargo, sabemos que fue comprada a un anticuario en Barcelona y que según su vendedor procedía de una masía abandonada (Sanmartí 1986, 261). Se trata de un plato poco hondo, con borde plano y decorado, y un pie alto y vertical que le fue añadido con posterioridad (Fig. 8.1). Originalmente disponía de un asa que hoy está perdida. En la parte interior del recipiente hay un umbo ligeramente descentrado con perforación. El plato tiene una decoración incisa en forma de espiga, un cordón liso, una guirnalda de motivos vegetales y finalmente una inscripción en latín que literalmente dice: teuderedi et deudates bita (m) X.P.S. (Christus) benedicat (CIL II $2 / 14,750$ ), que traducido podría significar «Que Cristo bendiga la vida de Teuderedus y Deudates», por lo que se debía tratar de la ofrenda de un matrimonio formado por el varón y la mujer. Alrededor de la perforación del fondo exterior hay grabados una serie de círculos concéntricos. Actualmente no se conoce ningún otro resto que ofrezca esta cronología en Onda, por lo que por el momento es muy difícil poder adscribir la pieza a esta localidad.

\section{LOS PROCESOS DE INTERCAMBIO}

Desde el final del siglo III hasta la mitad del V, en Sagunto y su territorio a través de la cultura material que se ha encontrado en las excavaciones se confirma la existencia de fluidas relaciones comerciales con el norte de África y Oriente. En Benicató (Nules), la Torrassa (Vila-real), el Castell (Onda), el Palau o Sant Gregori (Burriana), entre otros yacimientos, se han registrado materiales de esta época. $\mathrm{Si}$ 
analizamos las diferencias que existen en las villas durante la Antigüedad tardía, el siglo III debió ser un periodo de ciertas dificultades. Uno de los temas más difíciles de resolver por parte de los investigadores está relacionado con los efectos que debió tener la invasión franca del 264 en el municipio saguntino y en la Plana de Castellón. Desde luego en el norte de la comarca de la Plana la disminución de hábitats es constante, aunque sabemos que esta zona ya estaba menos poblada durante el Alto Imperio. Respecto al Mas d’Aragó, yacimiento que fue descubierto en 1980, se conoce un complejo industrial muy interesante formado por cuatro hornos de cerámica y otro relacionado con la metalurgia, junto a una serie de habitaciones relacionadas con ambas actividades. Además de un pequeño tesoro de 53 monedas altoimperiales destaca el hallazgo de cerámicas de los siglos V a. C. al X d. C. lo que no denota que hubo períodos de abandono (Borrás 1987-1988, 390).

Por otro lado, a los puertos de Saguntum y Dertosa se les ha otorgado un papel importante a la hora de distribuir las importaciones en esta franja costera. Sabemos que el comercio continuó activo en esta época, pues se han documentado importaciones africanas y en el siglo V se ha estudiado la llegada de productos gálicos (Aranegui 1982; Benedito 2013, 183). También se han encontrado materiales característicos del norte de la Meseta. En el territorio saguntino el Grau Vell fue el único puerto que continuó activo hasta el siglo VI. Al Norte, el fondeadero de Piedras de Barbadas, en la desembocadura de la rambla Cervera, en Benicarló, y el puerto de Dertosa, se encargarían de redistribuir sus mercancías en este largo periodo por los yacimientos localizados al norte de la provincia de Castellón (Fernández 1992, 112-20).

Hasta la primera mitad de la quinta centuria, Saguntum apoyó su economía en una relación comercial ininterrumpida con las provincias africanas. Importó sobre todo sigillatas africanas $\mathrm{C}$, que se han registrado en los yacimientos de l'Alqueria (Moncofa), Sant
Josep (la Vall d'Uixó), l'Alter (Xilxes), el Palmar (Borriol), el Castell (Onda), Benicató (Nules) y la Torrassa (Vila-real). La africana D evidencia un comercio marítimo desde mediados del siglo IV hasta mediados del V. Por otro lado, las cerámicas Hayes 99 y Hayes 104 documentadas en Benicató y el Tancat, están fechadas en el siglo VI, en plena época visigótica, lo que sin duda permite hablar de una continuidad en el comercio de las cerámicas africanas en este periodo. Estas producciones se acompañan de lucernas, como las que aparecieron en el poblado de Sant Josep y en el Pou d'en Llobet, en Albocàsser (Fig. 8.2. y 8.3). En esta etapa se importó sobre todo cerámica estampada, que se ha encontrado en la mayoría de asentamientos del territorio de Sagunto. Se trata de un tipo de cerámica decorada con motivos cristianos como la que se halló en la villa de Benicató.

En el siglo $\mathrm{V}$ llegaron también ciertos productos gálicos, concretamente sigillata gala estampada, más conocida como "derivada de la sigillata paleocristiana", que fue exportada por toda la costa del Mediterráneo occidental y que aparece, por ejemplo, en la Torre del Mal Paso; o la cerámica lucente en Benicató y Sant Josep. En esta época también aparecen materiales que son característicos del norte de la Meseta, la cerámica hispánica tardía sobre todo y piezas de oro o metalistería (broches de cinturón, cuchillos del tipo "Simancas" o arneses equinos de bronce), que producidos en los valles del Ebro y Duero entrarían a través de los pasos naturales que conectan el valle alto del Duero, por las llanuras de Teruel y el valle del río Palancia con la costa.

Se conoce también la existencia de un comercio de vidrio soplado a molde que era producido fuera de la península. Muy interesante es la botella de vidrio de Sant Josep con la representación de una doble cara de Cupido (Fig. 9.8). Este tipo ha sido documentado en yacimientos del sudeste de Francia en el siglo V, mientras que en la Península se ha encontrado en la necrópolis de el Albir (Benedito 2015, 216). 

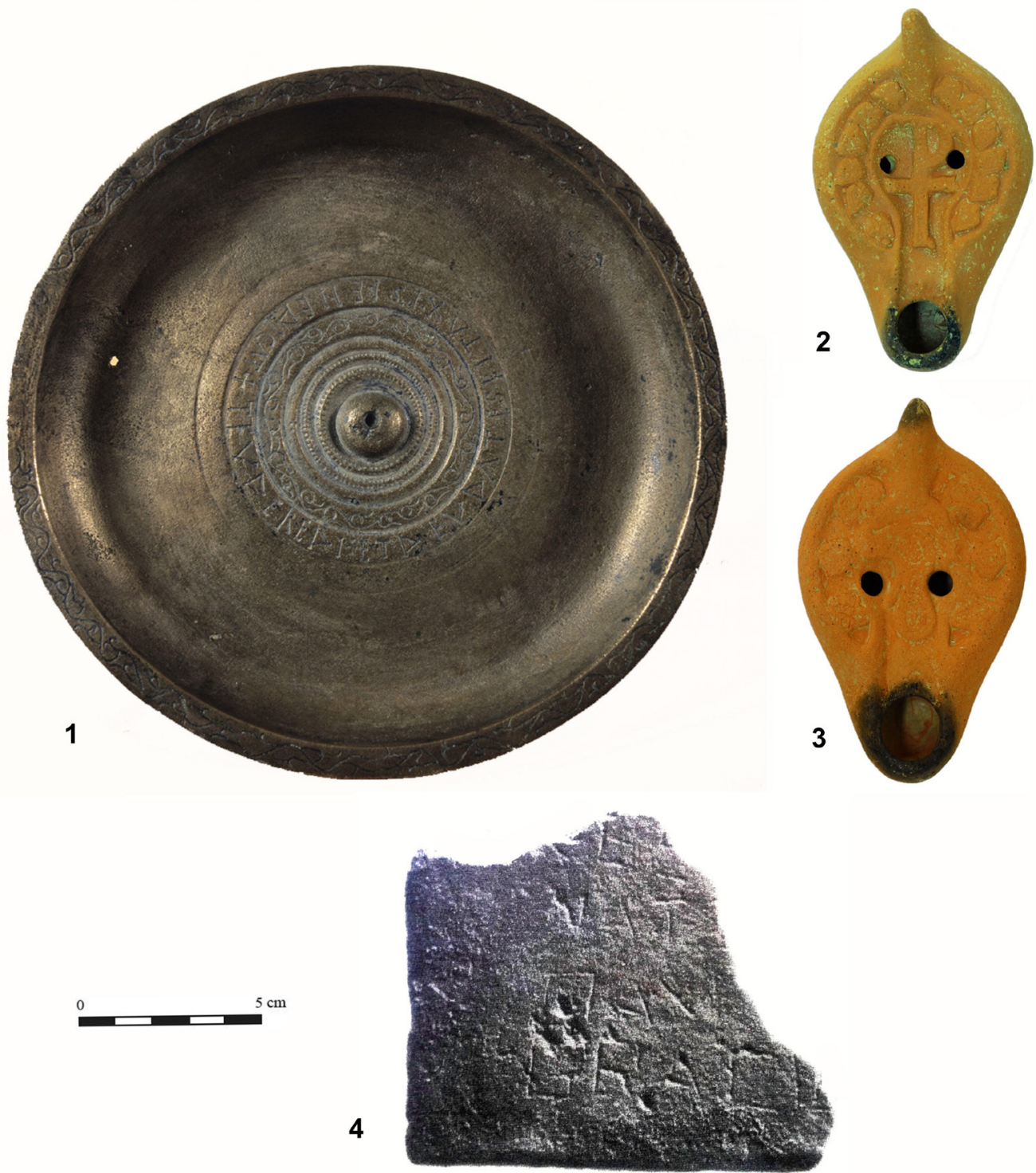

Figura 8. (1) Patena litúrgica de bronce supuestamente hallada en Onda. Fuente: Museu d'Arqueologia de Catalunya. (2 y 3) Lucernas africanas con motivos cristianos, Pou d’en Llobet, Albocàsser. Foto: autores. (4) Fragmento de una inscripción sobre piedra caliza de escritura incisa, Benicató, Nules. Fuente: Corell 2002.

La crisis política sin duda perjudicaría las relaciones comerciales que se realizaron en la costa de Sagunto, pero lo cierto es que durante la primera mitad de siglo continuó un comercio fluido en Benicató, la Torrassa, el Castellar, Torre la Sal, el Tancat o Sant Josep. Entre la segunda mitad del siglo V y el VI, parece claro que no hubo una paralización del comercio pese a las destrucciones documentadas en Valentia o en el Portus Sucronem, en Cullera, durante la primera mitad del siglo V. Algunos hallazgos de cerámica del interior del Alto Palancia y en Torre la Sal, demuestran que también en estas áreas se da una continuidad 
del comercio con África. En esta centuria llegan también algunos artículos del Mediterráneo oriental, cerámicas de origen mediterráneo como la Late Roman C o Phocaean Red Slip ware y la sigillata chipriota. En el Mas d'Aragó se ha encontrado sigillata gálica, hispánica tardía y claras norteafricanas (Fernández 2006, 271-301). Respecto a la procedencia de otros productos como el vidrio, las producciones del Rin marcarán las preferencias de este siglo; sin embargo, ciertos objetos de procedencia oriental son los que tienen mayor protagonismo (Benedito 2015, 245).

Un nivel registrado en l'Alqueria (Moncofa) apunta también hacia una cronología tardoantigua principalmente debido a la notable presencia de producciones africanas (Oliver y Moraño 1998, 387). Algunos hallazgos aislados aparecen en el interior del Alto Palancia, los hallazgos de Jayar, Arco Fuentes (ambos en el término de Soneja) y Mas de Marín (Segorbe) (Járrega 1998, 360), y en Torre la Sal (Ribera de Cabanes), se trata de un fragmento de sigillata africana $\mathrm{D}$ Hayes 104, que se puede fechar en el siglo VI (Sanfeliu y Flors 2009, 328), lo que demuestra que también en esta área se da una continuidad del comercio con el norte de África a lo largo del siglo V e inicios del VI. Durante la segunda mitad del VI el reino vándalo asentó su estructura en esa zona, lo cual sin duda debió favorecer una normalización del comercio de ciertos productos africanos. Y como se ha comprobado en ambientes hallados en Tarragona, Barcelona y Mataró, las buenas relaciones entre los reinos vándalo y visigodo propiciarían que esta zona costera catalana pasara a ser un mercado destacado de material africano (Járrega 2010, 166).

Los objetos concernientes al último tercio del siglo VI y principios del VII que se han hallado en las excavaciones después de la conquista bizantina del sudeste de Hispania en el 552, por ejemplo, las cerámicas romanoebusitanas tardías de los yacimientos del Tancat (Cabanes) y el Sitjar Baix (Onda) (Sanfeliu y Flors 2009, 331-34), parecen revelar que continúa habiendo un interesante volumen de importaciones en la costa este peninsular dentro del tráfico comercial del mediterráneo central y occidental.

\section{Conclusiones}

Por regla general, cuando nos enfrentamos al registro arqueológico de la tardoantigüedad $y$ en concreto del periodo visigodo que ofrece Sagunto, nos encontramos con un panorama que ha generado un conocimiento centrado únicamente en ciertos objetos y construcciones. Pero el paisaje arqueológico que ofrece la ciudad y su territorio en época tardoantigua a partir de nuevos descubrimientos comienza a semejarse al de otras ciudades hispanas, con un centro urbano heredado del mundo romano. Se asiste a la transformación de la civitas, utilizando y modificando la red viaria y los edificios de acuerdo a nuevos patrones de ocupación y a pesar de la reducción del espacio ocupado, es patente la preocupación por el mantenimiento, reparación y reforma de las principales estructuras urbanas, como es el caso de las murallas y parte del viario principal. Aunque algunos edificios monumentales habían sido ya desmantelados para construir probablemente las murallas, otros se conservan y mantienen, ofreciendo muestras de continuidad de uso y ocupación, aun con modificaciones. En cuanto al interior del recinto saguntino parece mostrar, por el momento, un uso civil sin construcciones religiosas.

Partiendo de la base de la pervivencia de un concepto equivalente al territorium de época romana que definiría el espacio administrado fiscalmente por las ciudades en época tardía, la pérdida de importancia del municipio romano de Saguntum desde finales del siglo IV y sobre todo en el V, nos pone sobre la pista de la asunción por parte de Valentia y también Dertosa de la administración de, tal vez, una parte de su antiguo territorium, pero no lo sabemos con certeza. En el marco de la descentralización administrativa y 
fiscal que tiene lugar en el Bajo Imperio, y probablemente sin la capacidad de gestionar la totalidad del territorio, Sagunto pudo adscribir su explotación a otra sede, es decir, a un centro que sí que fuera capaz de resolver esta transformación administrativa. En nuestro caso, probablemente implicó la adscripción de parte de estas tierras a manos de la ciudad más cercana, esto es Valentia, como hemos visto una ciudad más fuerte en el marco regional a partir de la quinta centuria. Tampoco debemos olvidar que el obispado de Tortosa en la Edad Media alcanzaba su dominio hasta Almenara, circunstancia que más tarde, en el siglo XIX, fue utilizada para trazar los actuales límites provinciales. Por lo que esta gran extensión del obispado de Tortosa tuvo que hacerse a costa de parte del antiguo territorio de Saguntum.
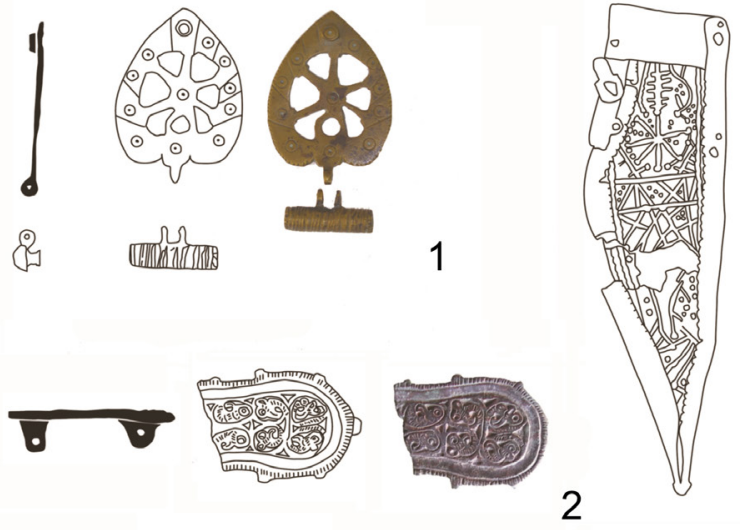

2
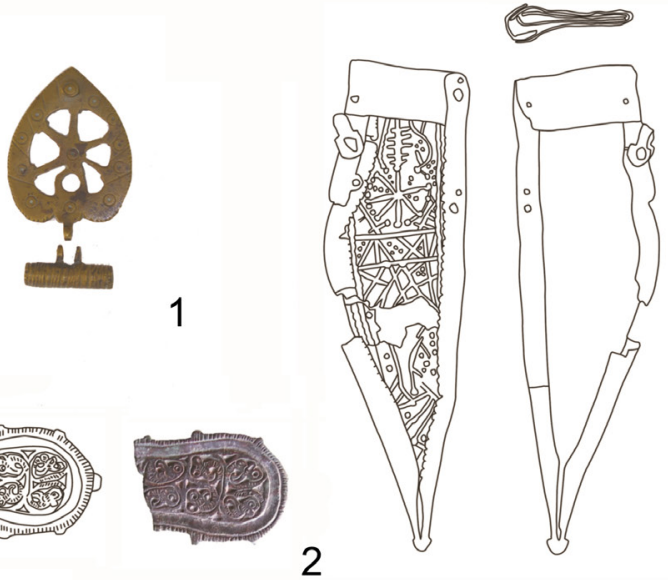

1
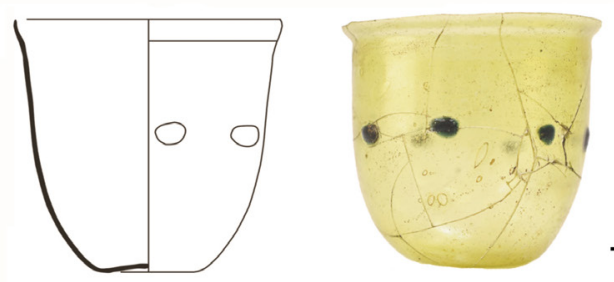

7
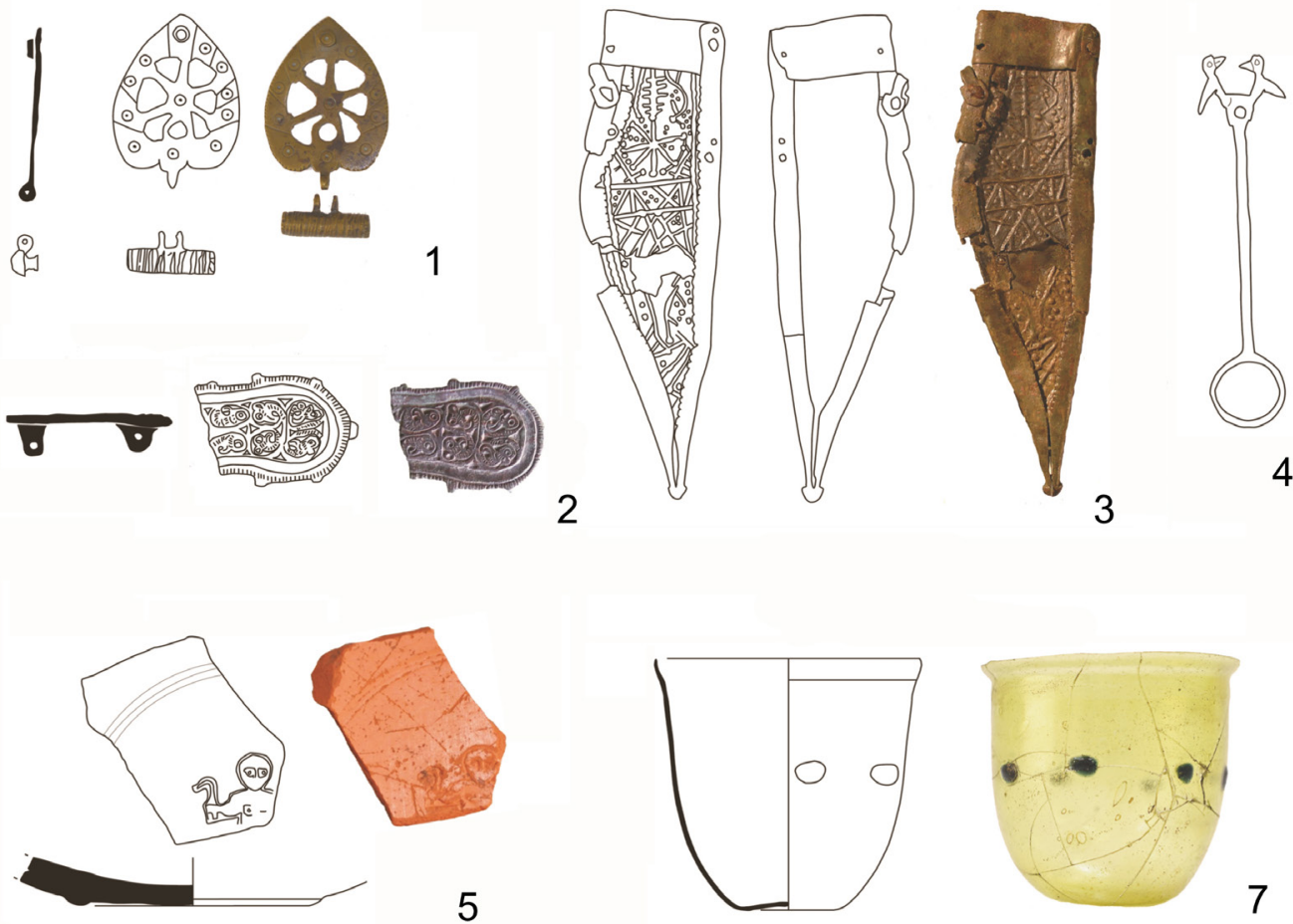
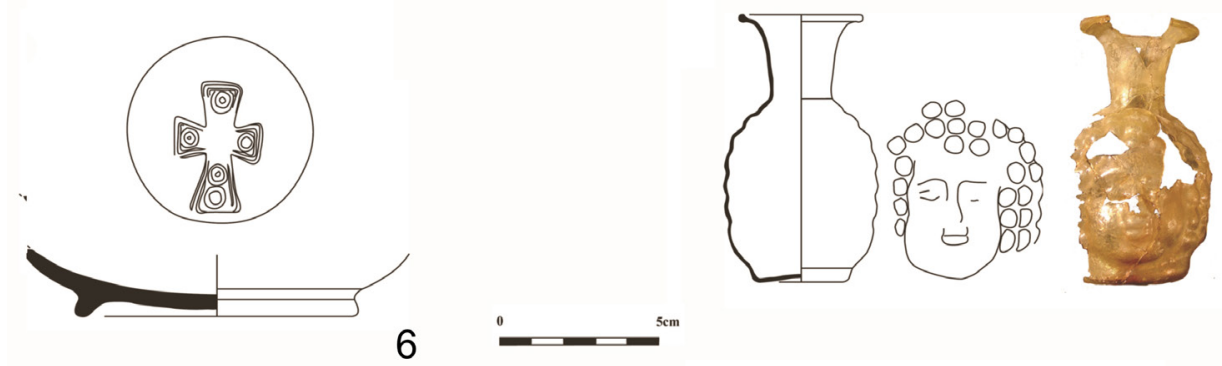

Figura 9. (1) Pieza de arnés de bronce, Sant Josep, la Vall d’Uixó. (2) Placa de cinturón de bronce, la Font d'Horta, Cinctorres. (3) Funda de puñal de bronce "tipo Simancas", Sant Josep. (4) Osculatorium, el Portell de Morella. (5 y 6) Cerámicas con motivos cristianos, Benicató, Nules. (7) Vaso de vidrio del tipo Isings 12-Morin Jean 75, l'Hostalot, Vilanova d'Alcolea. (8) Botella con la representación de una doble cara de Cupido, Sant Josep. Ilustración: autores. 
Sin embargo, Sagunto quizá pudo ejercer un dominio directo sobre el territorio más inmediato, un suelo inmerso en un auténtico vacío episcopal que, como se ha comentado, se encontraba alejado de las sedes visigodas preexistentes.

Por otro lado, varios estudios han vinculado la centuriación, es decir, el reparto de las tierras agrícolas a partir de los nuevos planteamientos administrativos municipales de época romana, con el poblamiento inmediato a Saguntum (González 2006; García-Prósper et al. 2006; Járrega 2013), pero la mayoría de las villae que surgieron a raíz de este proceso estarían ya abandonadas en este territorio a principios del siglo V. Sabemos que desde época bajoimperial, sobre todo a partir del siglo IV, se produce una paulatina reducción del número de asentamientos rurales, al igual que sucede en los territorios vecinos. Por lo que parece que el conjunto del territorio saguntino iniciaría un proceso generalizado de abandono de yacimientos a partir del momento en que la ciudad se colapsó. Solo unas pocas de estas villae superaron el siglo $\mathrm{V}$ y, en principio, a falta de llevar a cabo estudios de detalle, no se localizan en lugares donde más tarde se desarrollaron alquerías musulmanas, y aunque su abandono demuestra una falta de continuidad en el hábitat, deberemos en futuros trabajos comprobar si se da una correspondencia entre el espacio vinculado a la ciudad medieval y las centurias romanas. A pesar de que la comprobación de este hecho sobre el terreno tropieza con dificultades derivadas de la intensa explotación agrícola que ha sufrido la zona, se deberá estudiar la superposición de la red de acequias al parcelario para demostrar si se dio la reutilización de los antiguos espacios de cultivo. En principio, los datos previos demuestran que los hábitats no coinciden pero sí los espacios agrícolas.

En todo caso, aunque la ciudad continúa habitada, la decadencia de la actividad productiva de su territorio se ve reflejada en el final del funcionamiento del puerto comercial del Grau Vell. Asentamiento portuario de gran importancia, éste había sido concebido como una parte inseparable del municipio romano de Saguntum, y hasta el siglo VI parece concentrar las importaciones marítimas de la ciudad, tal y como han demostrado las excavaciones arqueológicas de este enclave. $\mathrm{Y}$ a pesar de la retracción comercial que se ha constatado a través del puerto, las actividades productivas del territorio no desaparecen totalmente mientras que la población participa de los circuitos comerciales de la época, que incluyen productos mediterráneos y africanos. La crisis política del siglo V, en efecto, llegó a perjudicar las relaciones comerciales, como demuestra la disminución de los intercambios en Benicató, el Castellar o Sant Josep, es decir, aquellos yacimientos donde se han constatado niveles tardoantiguos. Entre la segunda mitad del siglo $\mathrm{V}$ y el VI, los contextos hallados en el territorio de Sagunto hacen pensar que aumentó la distribución de cerámicas africanas. En cualquier caso, parece claro que no hubo una exclusión del comercio.

Las invasiones y la consecuente pérdida de autoridad institucional, debió provocar el uso de la expresión Murus vetus, en alusión al estado de abandono de la antigua ciudad clásica y a esos "muros viejos" con los que probablemente desde el siglo VI se le identificaba. En este sentido, las excavaciones arqueológicas que se han llevado a cabo en la ciudad han sacado a la luz estructuras arrasadas por el expolio de materiales que tuvo lugar en esta época en la zona extramuros, por lo que quizá el interior de las murallas pudo conservar el nombre de Sagunto y el campo de ruinas exterior con el tiempo pasase a adoptar el de murus veteris. En época árabe el topónimo Sagunto debió desaparecer totalmente, pues en las primeras crónicas árabes conocidas del siglo $\mathrm{X}$ ya no se conserva (Barceló 2009), pero sí el del origen romano de las ruinas (Franco 2006). Las crónicas medievales, desde el Cid hasta Jaume I, continuaron refiriéndose a la ciudad con los topónimos derivados de Murus Vetus, Murviedro y Murvedre. 


\section{Bibliografía}

Alapont, L. y Tormo F. J. 2005. La necròpolis i les troballes monetàries del jaciment visigòtic de la Senda de l'Horteta en Alcasser (Valencia). En Gurt, J. M. y Ribera, A., (coords.), VI Reunió d'Arqueologia Cristiana Hispànica: les ciutats tardoantigues d'Hispania. Cristianització i topografia, 317-322. Barcelona: Col-lecció Monografies de la Secció Històrico-Arqueològica IX.

Albertini, E. 1923. Les divisions administratives de l'Espagne Romaine. Paris: E. de Boccard.

Alcina, J. 1950. Las ruinas romanas de Almenara (Castellón). Informe preliminar. Boletín de la Sociedad Castellonense de Cultura 26, 92-128.

Alfonso, J. y Miguélez A. 2013. La villa romana del Camino de Vinamargo (Castellón). En Alapont. Ll. y Martí, J. (eds.), Actas III Jornades d'Arqueologia de València i Castelló, 87-98. Valencia: Ajuntament de València.

Aranegui, C. 1982. Excavaciones en el Grau Vell, Sagunto, Valencia. Campañas de 1974 y 1976. En Serie TV del SIP 72. Valencia: Museu de Prehistòria de València.

Aranegui, C. 2004. Saguntum. Oppidum, emporio y municipio romano. Barcelona: Edicions Bellaterra.

Arasa, F. 1999. Noves propostes d'interpretació sobre el conjunt monumental de la Muntanyeta dels Estanys d'Almenara (la Plana Baixa, Castelló). Archivo de Prehistoria Levantina 23, 301 358.

Arasa, F. 2000. El conjunto monumental de Almenara (la Plana Baixa, Castelló). En Ribera A. (coord.), Los orígenes del Cristianismo en Valencia y su entorno, 113-118. Valencia: Ajuntament de València.

Arasa, F. y Flors E. 2009. El mundo romano y la Antigüedad Tardía. En Flors E. (coord.), Torre la Sal (Ribera de Cabanes, Castellón). Evolución del paisaje antrópico desde la prehistoria hasta el medioevo. Monografies de Prehistòria i Arqueologia Castellonenques, 8, 523-528. Castellón: Diputació Provincial de Castelló.

Aurrecoechea, J. 2007. Arneses equinos de época romana en Hispania. Sautuola 13, 321-344.

Barceló, C. 2009. Los falsos Sagunt de las fuentes árabes. Al-qantara 30(1), 237-243.

Benedito, J. 2013. Redes de distribución y comercio de época romana en el territorio de la provincia de Castellón a través de los testimonios de arte suntuario y de instrumentum domesticum decorado. Millars 36, 169-199.

Benedito, J. 2015. El comercio romano de ornamentos artesanales en el norte de la Comunidad Valenciana. Castellón: Publicacions Universitat Jaume I.

Berrocal, P., Salvador L., Garibo J. y Vila A. 2004-05. Intervención arqueológica en el yacimiento arqueológico del Sitjar Baix, Onda (La Plana Baixa). Quad. Pre. Arq. Cast. 24, 389-396.

Borrás, C. 1987-88. Avance de las excavaciones de la villa romana del Mas d’Aragó. CPAC 13, 379-397.

Burriel, J. M., Jiménez J. L. y Rosselló M. 2019. Las fases tardorromana y visigótica de la villa de l'Horta Vella (Bétera, València). En tiempos de los visigodos en el territorio de València, 67-76. Valencia: Museu de Prehistòria de València.

Corell, J. 1989. Inscripción del obispo Anesio, atribuida erróneamente a Justiniano. Saitabi 39, 63-72.

Corell, J. 2002. Inscripcions romanes del Pais Valencià. Saguntum i el seu territori (IRSAT). Valencia: Fonts Històriques Valencianes 12. 
De Antonio, J. M. y Pérez R. 2019. El edificio visigodo de Els Casals del Mas de Sabater, Morella, Els Ports (Castelló). En tiempos de los visigodos en el territorio de València, 51-58. Valencia: Museu de Prehistòria de València.

Escrivà, V. 2014. La ciudad romana de Edeta (Llíria, Valencia). En Olcina, M. H. (ed.), Ciudades romanas valencianas, 123-142. Alicante: MARQ.

Escrivà, V., Martínez, C. y Vidal, X. 2005. Edeta en la Antigüedad tardía (Llíria, Valencia). En Gurt, J. M. y Ribera, A. (coords.), Actas VI Reunió d'Arqueologia Cristiana Hispànica: les ciutats tardoantigues d'Hispania. Cristianització i topografía, 267-278. Barcelona: Institut d'Estudis Catalans.

Espinosa, A., Ruiz, D. y Marcos, A. 2019. El territorio de Allon. En tiempos de los visigodos en el territorio de València, 149-154. Valencia: Museu de Prehistòria de València.

Fernández, A. 1992. Las relaciones mediterráneas. En Historia de Castellón, 112-120. Castellón: Ed. Prensa valenciana, S. A. Castellón.

Fernández, A. 2006. Aproximación a la villa romana del Mas d’Aragó (Cervera del Maestrat, Castellón): producción cerámica del alfar. Quad. Pre. Arq. Cast. 25, 271-301.

Ferrer, J. J., Benedito, J. y Melchor, J. M. 2018. A new impression of the Roman city of 'Saguntum' (Spain) based on recent findings. Archeologia Classica 69 (8), 357-378.

Ferrer, J. J., Oliver, A. y Benedito, J. 2016. Saguntum y La Plana: una ciudad romana y su territorio, Castellón: Diputación Provincial de Castellón.

Franco, F. 2006. Sagunto/Murbitar en el periodo islámico. Su historia a través de los textos. En De Murbiter a Morvedre, 47-65. Valencia.

García, L. A. 2017. España siglo V. La monarquía goda balta y la diócesis de las Españas. Madrid: Real Academia de la Historia.

García-Prósper, E., Guérin, P., De Madaria, J. L. y Sánchez, P. 2006. Campaña de prospección en la centuriación romana de Sagunto. En García, E., Guérin, P., De Madaria, J. L. y Sánchez, P. (eds.), Catastros, hábitats y vía romana, 247-298. Valencia: Generalitat Valenciana.

Gimeno, H. 1988. Artesanos y técnicos en la Epigrafía de Hispania, Barcelona: Universitat Autònoma de Barcelona.

Gil, P., Negre, M. C., Polo M., Miquel, M. J. y Puchalt, F. J. 1996. Salud bucal en época tardorromana: necrópolis La Unión, La Vall d'Uixó. En Actes del Primer Congrés d'Investigació per a Estudiants de Medicina i Ciències de la Salut, 106. Tarragona: Universitat Rovira i Virgili.

González, R. 2006. Bonificación de zonas palustres en el ager saguntinus. En García-Prósper, E., Guérin, P., De Madaria, J. L. y Sánchez. P. (eds.), Catastros, hábitats y vía romana, 215-246. Valencia: Generalitat Valenciana.

Guilabert, A., Ronda, A. y Tendero, M. 2019. Ilici y la evolución territorial entre los siglos VI y VII. En tiempos de los visigodos en el territorio de València, 141-148. Valencia: Museu de Prehistòria de València.

Guinot, E. 2007. Morvedre: història d'una vila valenciana medieval. Braçal 35-36, 95-134.

Gusi, F., Fernández, M. Á. y Fernández, A. 2008. El patrimonio histórico-arqueológico de Castellón y su explotación turística: perspectivas de futuro. Quad. Pre. Arq. Cast. 26, 169-196.

Gusi, F. y Olaria, C. 1977. La villa romana de Benicató (Nules, Castellón). Cuadernos de Prehistoria y Arqueología de Castellón 4, 101-144.

Gutiérrez, S. 2004. Ilici en la Antigüedad tardía. La ciudad evanescente. En Abad, L. y Herández, M. S. (eds.), Iberia, Hispania, Spania. Una mirada desde Ilici, 95-110. Alicante: Fundación Universitaria de Investigación Arqueológica L’Alcúdia. 
Gutiérrez, S. 2013. De Teodomiro a Tudmir. Los primeros tiempos desde la arqueología (s. VIIIX). En De Mahoma a Carlomagno. Los primeros tiempos (siglos VII-IX), Actas XXXIX Semana de Estudios Medievales, 229-283. Estella: Gobierno de Navarra.

Hortelano, I. 1992. Excavaciones arqueológicas en la iglesia de San Salvador de Sagunto (febreromarzo, junio 1992). Arse 27, 44-61.

Huguet, E., Macias, J. M., Ribera, A., Rodríguez, F. y Rosselló, M. 2019. València la Vella. Un yacimiento todavía por descubrir. En tiempos de los visigodos en el territorio de València, 97 104. Valencia: Museu de Prehistòria de València.

Hurtado, T., Mas P., Ramón, M. A. y Rosselló, M. 2008. Un nivel de destrucción del siglo V d. C. en el Portus Sucronem (Cullera, Valencia). Contexto material. Quad. Pre. Arq. Cast. 26, 95-142.

Járrega, R. 1998. El poblamiento romano en la comarca del Alto Palancia (Castellón). Estado actual de nuestros conocimientos. Quad. Pre. Arq. Cast. 19, 349-369.

Járrega, R. 2010. El comercio con África y el Mediterráneo en las costas orientales de Hispania entre los siglos V y VII. Las producciones cerámicas. En Ebanista, C. y Rotili, M. (eds.), Ipsam Nolam Barbari Vastaverunt. L'Italia e il Mediterraneo occidentale tra il V secolo e la metà del VI, Atti del Convegno Internazionale di Studi Cimitile-Nola-Santa Maria Capua Vetere, 163-181.

Járrega, R. 2011. La Plana romana. Castellón: Diputació Provincial de Castelló.

Járrega, R. 2013. Nuevos datos para el estudio de una posible centuriación en la Plana en época romana. Millars 36, 227-257.

Járrega, R. e.p. La economía y el comercio en Saguntum y en la Plana en época romana, a través del estudio de las ánforas. En Salve Lucrum. Homenaje al profesor Juan José Ferrer. Barcelona: editorial Calambur.

Jiménez, J. L. y Burriel, J. M. 2007. L’Horta Vella (Bétera, Valencia). Saguntum-PLAV 39, 193-197. López, M. 1991. El nivel de abandono del Grau Vell. Las sigillatas de producción africana. En Aranegui Gascó, A. (ed.), Saguntum y el mar, 98-102. Valencia: Conselleria de Cultura, Educació i Ciència.

López, F. 2009. La moneda del reino visigodo de Toledo: ¿por qué? ¿para quién?. Mainake 31, 175-186.

López, F., Delaporte S., Benedito J., Claramonte M. y Melchor J. M. 2014. A propósito de unas púas de rastrillo y de otros materiales metálicos de época medieval procedentes de Sagunto. Quad. Preh. Arq. Cast. 32, 241-256.

Lorenzo, R. 2007. L'Alcúdia d'Elx a l'Antiguitat tardana. Anàlisi historiogràfica i arqueològica d'Ilici dels segles V-VIII. Alicante: Publicacions Universitat d'Alacant.

Lorenzo, R. 2016. Ilici en la Antigüedad tardía. Ciudad y territorio del ocaso imperial al pacto de Tudmìr. Tesis Doctoral. Universitat d'Alacant.

Mansilla, D. 1959. Orígenes de la organización metropolitana de la iglesia española. Hispania Sacra 12, 255-290.

Martínez, R., Molina, M., Nuñez, G., Rosselló, M., Hurtado, T., García-Prósper, E., Polo, M. e García, I. 2018. Senda de l'Horteta. Nuevas aportaciones al estudio de un asentamiento visigodo. En Matamoros, C., Tendero, F. E., Alapont, Ll. y Alfonso, J. (eds.), Actes de les Jornades d'Arqueologia de la Comunitat Valenciana (2013-2015), 191-203. Valencia: Generalitat Valenciana.

Negre Muñoz, M.C., Polo Cerdá, M., Gil Pitach, P., Miquel Feucht, J. y Villalaín Blanco, J. D. 1997. Alteraciones dentales previas a la erupción en la necrópolis de La Unión (siglo VI). En Macias, M. M., y Picazo, J. E. (eds.), La enfermedad en los restos humanos arqueológicos. Actualización conceptual y metodológica, Actas del IV Congreso Nacional de Paleopatología, 351-356. Cádiz. 
Oliver, A. y Moraño, I. 1998. El yacimiento romano de l'Alqueria de Moncofar (Castellón). Quad. Pre. Arq. Cast. 19, 371-393.

Pérez Rodríguez, F. 1999. La tumba femenina germano oriental del yacimiento de l'Hostalot (La Vilanova d'Alcolea, Castellón). En Actas Congreso Nacional de Arqueología XXIV, 581-585. Cartagena.

Pliego, R. 2008. La acuñación monetaria en el reino visigodo de Toledo: el funcionamiento de las cecas. En Campo, M. (ed.), Els tallers monetaris. Organització i producció, 117-141. Barcelona: Museu Nacional d'Art de Catalunya.

Polo, M. y García-Prósper, E. 2005. Estudio bioantropológico de los restos óseos hallados en el interior de la cloaca de la vía romana del 'solar de la Morería' de Sagunto. Arse 39, 209-228.

Poveda, A. 2005. Aproximación al urbanismo de Ilici Augusta durante la Antigüedad tardía. En Gurt, J. M., y Ribera, A. (coords.), VI Reunió d’Arqueologia Cristiana Hispànica: les ciutats tardoantigues d'Hispania. Cristianització i topografia, 323-344. Barcelona: Col-lecció Monografies de la Secció Històrico-Arqueològica IX.

Poveda, A. 2007. De "monasterium" visigodo a "al-munastir" islámico. El Monastil (Elda, Alicante) durante la alta edad media. En López, J., Martínez, A.M. y Morín, J. (coords.), Monasteria et territoria. Elites, edilicia y territorio en el Mediterraneo medieval (siglos V-XI), Actas del III Encuentro Internacional e Interdisciplinar sobre la alta Edad Media en la Península Ibérica, 181-202. Madrid: Universidad Autónoma de Madrid.

Ramos, R. 1995. Noticia sobre la basílica paleocristiana de Ilici. En Actas del XXI Congreso Nacional de Arqueología, III, 1231-1232. Zaragoza: Diputación General de Aragón, Departamento de Educación y Cultura.

Ramos, A. 1972. Un cancel visigodo en La Alcudia de Elche. Pyrenae 8, 167-171.

Ribera, A. 2003. Valentia: del foro al área episcopal. En García Moreno, L. A., Gil Egea, M. ${ }^{a}$ E., Rascón Márzquez, S. y Vallejo Girvés, M. (eds.), Santos, obispos y reliquias, Acta Antiqua Complutensia III, 45-83. Alcalá de Henares: Universidad de Alcalá. Servicio de Publicaciones.

Ribera, A. 2005. Origen i desenvolupament del nucli episcopal de València. En Gurt, J. M. y Ribera, A. (coords.), VI Reunió d'Arqueologia Cristiana Hispànica: les ciutats tardoantigues d'Hispania. Cristianització i topografia, coord. por., 207-243. Barcelona: Colllecció Monografies de la Secció Històrico-Arqueològica IX.

Ribera, A. La ciudad de Valencia durante el periodo visigodo. Zona Arqueológica. Recópolis y la ciudad en época visigoda 9, 302-320.

Ribera, A. y Rosselló, M. 2000. La ciudad de Valencia en época visigoda. En Los inicios del cristianismo en Valencia y su entorno, 151-164. Valencia: Grandes Temas Arqueológicos, 2.

Ribera, A. y Rosselló, M. 2009. Valentia en el siglo VII, de Suinthila a Teodomiro. Anejos del AEspA 51, 185-203.

Ribera, A. y Rosselló, M. 2019. Valentia: ciudad episcopal. En tiempos de los visigodos en el territorio de València, 59-66. Valencia: Museu de Prehistòria de València.

Ribera, A. y Rosselló, M. 2019. Pla de Nadal (Riba-roja de Túria), palacio de Teudmir. En tiempos de los visigodos en el territorio de València, 213-220. Valencia: Museu de Prehistòria de València.

Ripollès, P. P. 1980. Estudio numismático del yacimiento de Sant Josep (Vall d'Uixó, Castellón). En Actas II Simposi Numismátic de Barcelona, 211-215, Barcelona: Cymys.

Ronda, A. M., Alicia Luján y Vicent Sevila. 2018. El balneum oriental dels Banys de la Reina de Calp. Actuaciones arqueológicas 2012-2013. En Jornades d'Arqueologia de la Comunitat Valenciana 2013-2015, 147-156. Valencia: Generalitat Valenciana, Conselleria d'Educació, Investigació, Cultura i Esport. 
Rosas, M. 1980. Un nou jaciment amb materials del Ferro I: El Mas de Vito (Rossell, Castelló). Cuadernos de Prehistoria y Arqueología de Castellón 7, 291-293.

Rosas, M. 1984. El poblat ibero-romà de Sant Josep. Fonaments 4, 247-273.

Rosas, M. 1997. Algunes àmfores africanes i hispàniques del moment tardoromà del poblat de Sant Josep (La Vall d'Uixó, Castelló). En Annals de l'Institut d'Estudis Gironins. Hispània i Roma. D’August a Carlemany 37, 1161-1168. Girona: Institut d'Estudis Gironins.

Rosselló, M. 2000. El Conjunto Monástico de la Punta de l’Illa de Cullera. En Ribera, A. (coord.), Los orígenes del cristianismo en Valencia y su entorno, 143-150. Valencia: Grandes Temas Arqueológicos, 2.

Rosselló, M. 2019. El monasterio de Punta de l'Illa de Cullera (València). En tiempos de los visigodos en el territorio de València, 77-82. Valencia: Museu de Prehistòria de València.

Rovira, M. L. 1993. Urbanismo y poblamiento de la Vall d'Uixó. Reflexiones en torno al nacimiento de una ciudad. En Azuar Ruiz, R., Gutiérrez Lloret, S. y Valdés Fernández, F. (eds.), Urbanismo medieval del País Valenciano, 221-229. Madrid: Ediciones Polifemo.

Sanfeliu D. y Flors, E. 2009. La cultura material. En Flors E. (coord.), Torre la Sal (Ribera de Cabanes, Castellón). Evolución del paisaje antrópico desde la prehistoria hasta el Medioevo, 269-359, Monografies de Prehistòria i Arqueologia Castellonenques 8. Castellón: Diputació Provincial de Castelló.

Sanmartí, E. 1986. Una patena visigoda d’ús litúrgic trobada a Onda (Plana Baixa, Castelló). Cuadernos de Prehistoria y Arqueología de Castellón 12, 261-266.

Tendero, M. y Ronda, A. M. 2014. La ciudad romana de Ilici (l'Alcúdia de Elche, Alicante). En Olcina, M. H. (ed.), Ciudades romanas valencianas: actas de las Jornadas sobre Ciudades Romanas Valencianas. Actualidad de la investigación historico arqueológica, celebradas en el MARQ los días 3 y 4 de diciembre de 2013 = Ciutats Romanes Valencianes : actes de les Jornades sobre Ciutats Romanes Valencianes, 226-242. Alicante: MARQ.

Trelis, J. 2011-12. La Canyada Joana (Crevillent, Alicante). Una villa romana del ager Ilicitanus. AnMurcia 27-28, 293-303. 